\title{
A Model for the Future Care of Acute Spinal Cord Injuries
}

\author{
E. H. BOTTERELL, A. T. JOUSSE, A. S. KRAUS, M. G. THOMPSON, M. WYNNE-JONES AND W. O. GEISLER
}

SUMMARY: This is a review of the total care of those acute spinal cord injury patients in Ontario during the years 1969 and 1970, from extrication and transportation following the accident to death, or the completion of primary definitive rehabilitation.

Information was extracted from the available ambulance records, the patients and many of the responsible physicians were interviewed personally. The study was detailed and intensive and included a review of each patient's hospital records in each hospital up to discharge from the rehabilitation programme into the community, or to a chronic care unit. The data was compiled in accordance with a detailed and lengthy questionnaire developed for this study.

The incidence of acute cord injuries in Ontario in 1969 and 1970 amounted to 244; in 1969, 15.9 per million population and in 1970, 13.6 per million. As in other studies road accidents took first place, followed by falls from a height; sports injuries ranked third and $65.7 \%$ of these were caused by diving into shallow water. Age incidence, and incidence by month, day of week and time of day were identified. Fridays and

RÉSUMÉ: II s'agit d'une étude du traitement complet des accidents aigus de la moelle épinière, du moment du sauvetage et du transport du blessé jusqu'à la mort ou la fin du premier

From the departments of Surgical Neurology, Clinical Anatomy and Community Health and Epidemiology, Queens University, Kingston; LyndHurst Hospital, Toronto; and the department of Rehabilitation Medicine. University of Toronto.

The W. E. Gallie Memorial Lecture derived from this paper was presented by Dr. E. H. Botterell at the 44th Annual Meeting of the Royal College of Physicians and Surgeons of Canada, January 1975.
Saturday afternoons in July and August are particularly hazardous.

The study continued to the end of 1974 by which time 34 deaths had been recorded. Peak incidence of death occurred within fourteen days of injury. The most common cause of death was respiratory in origin.

Geographical distribution was identified and the type of hospital treating the acutely injured patient.

Fourteen percent of persons with spinal column injury suffered progressive or sequential spinal cord damage both prior to and following medical contact. The incidence of pressure sores and genitourinary sepsis and calculosis was high in all types of hospitals. The effect of operative treatment was noted in the cases of complete quadriplegia and paraplegia.

Of the 133 survivors who undertook a rehabilitation program, $84 \%$ returned to their homes and 59\% achieved gainful employment or ongoing education.

The cost was determined of general hospital services and rehabilitation programmes.

A new model for the care of the spinal cord injury patients in Ontario was proposed.

stage d'un réhabilitation définitive, et ce lors des années 1969 et 1970 dans la province d'Ontario. 224 accidents furent ainsi étudiés en détail. Plusieurs conclusions et recommandations suivent.

It is reprinted by permission of the Editor of the Annals of the Royal College of Physicians and Surgeons.

This research project was supported by a Provincial Health Research Grant of the Ministry of Health, Province of Ontario.

Reprint requests to Dr. E. H. Botterell, Queens University, Kingston, Ontario, Canada. K7L. 3N6.
For any surgeon to be invited to give the W. E. Gallie Memorial Lecture is a singular honour, but for a resident of W. E. Gallie, it is also a deeply personal and memorable occasion.

Each of W. E. Gallie's residents has special reasons for warm and enduring affectionate loyalty. If one occasion had to be chosen as specially delightful and unforgettable, it would be the meeting of the Gallie Club in the United Kingdom in 1957. Dr. Gallie, an honourary Fellow of both Royal Colleges, entertained his residents and their wives at dinner, first in the Royal College of Surgeons in London and then at the Royal College in Edinburgh.

Dr. Gallie (Fig. 1) is standing in front of a painting of a meeting of the Fellows of the Royal College of Edinburgh in 1889 , chaired by the President, Joseph Bell; Douglas Argyll Robertson of Argyll Robertson Pupil fame is among the Fellows present.

Though few in number, each major spinal cord injury is devastating to the individual and to his family, and of great cost to the community. Until World War II these patients were without continuing expert total management by a physician or surgeon. The neurosurgeon and orthopedic surgeon moved on to new patients and new problems when their special skills were required no longer; the urologist had a vital continuing responsibility.

In 1936 in the Toronto General Hospital interest in acute cord injuries was at a high level. K. G. McKenzie (1935) at Robert Janes's suggestion had used tongs (Fig. 2) for skull traction without knowing that Crutchfield (1933) in Virginia had recently done so, on the sugges- 
tion of his chief, Claude Coleman. Crutchfield described using Edmonton extension tongs in his first case on 27 June 1932. Skull traction was the start of a new era in the management of fracture-dislocations of the cervical spine with and without spinal cord injury. In fact, probably the first surgeon to use tongs for skull traction was neither Crutchfield or McKenzie, but H. H. Hepburn of the University of Alberta. A. L. Hepburn (1975) recalls that his father constructed these tongs "from scrap steel rods, in the boiler room of the Old Strathcona Hospital, which became the University of Alberta Hospital.'

In this era Dr. Gallie $(1937,1939)$ was teaching that fracturedislocations of the spine with or without cord injury, should be reduced and immobilized as soon as feasible, as were fractures in general. Donald Munro (1936, 1943) of Boston, the father of the modern treatment of the paraplegic patient, had just introduced tidal irrigation for management of the paralyzed bladder - a combination of irrigation and siphonage.

In this setting, Dr. Gallie involved one of us (Botterell) in the care of one of his patients, a paraplegic with an unreduced lumbar fracturedislocation and suffering from severe genito-urinary sepsis. Working with tidal drainage, ankle deep in irrigation solutions of various colours, the G. U. sepsis was brought under control; the resident, the late Palmer McCormick, recorded "that tidal irrigation saved this patient's life." Dr. Gallie then did an open reduction. The record of this patient is included in a film demonstrating the treatment of three patients; each patient suffered severe but incomplete cord injury. Management in the acute stage was recorded, as was rehabilitation and recovery. The film, "Recovery Following Severe Injury to Spinal Cord and Cauda Equina", was presented first to the annual

\footnotetext{
* By "complete" cord injury is meant complete paralysis below the level of cord injury - complete loss of all modalities of sensation, including anal and rectal sensation, and complete visceral and sphincteric paralysis.
}

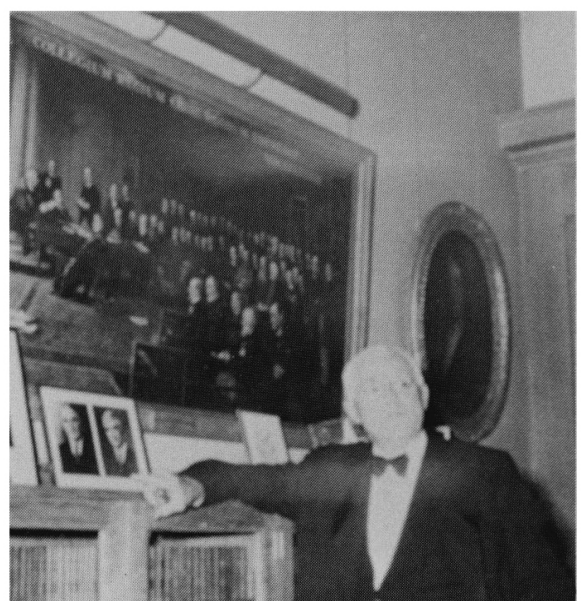

Figure 1-Dr. W. E. Gallie - standing in front of a painting of a meeting of the Fellows of the Royal College of Edinburgh in 1889 .

meeting of the Canadian Medical Association in 1939 (Botterell, 1939).

Fundamental conclusions valid in 1939 remain inescapable today.

1. Careful transportation in and outside hospital may save the cord.

2. No matter how severe the acute spinal cord injury, if any spinal cord function remains, astonishing recovery is possible.

3. Pressure sores are preventable.

4. The incidence of genito-urinary sepsis can be kept low.

5. From the moment of injury, every acute cord injury patient, complete* and incomplete, must be treated as having the potential for recovery.

New Treatment Techniques

In 1968, Albin, White, Acosta-Rua and Yashon reported that in animals,

Figure 2-Original McKenzie Tongs.

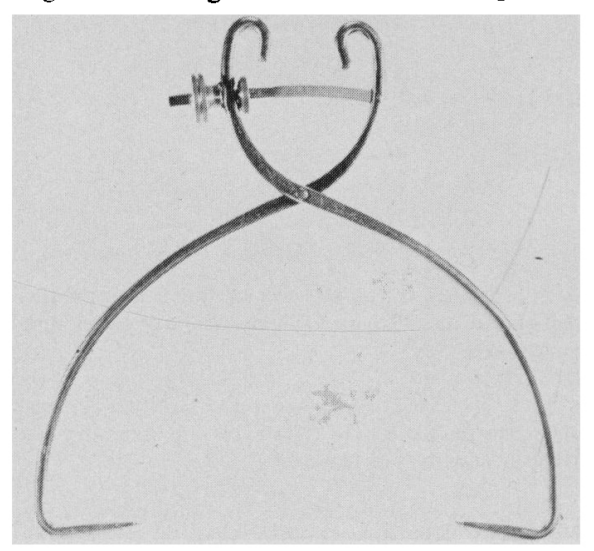

experimental paraplegia may be prevented in a significant percentage of cases after cord injury when local hypothermia was produced by irrigation - perfusion of the injured cord within four hours of injury. This remains an unsettled issue.

This work has triggered research into the pathology and treatment of acute cord injuries in centres in the U.S.A. and Canada. Experimental research into acute cord injuries has engendered new hope that a proportion of patients in whom the cord has not suffered immediate irreparable structural injury may be prevented from advancing from incomplete to complete cord injury; a proportion may have apparent clinically complete cord injury converted to incomplete cord injury with its potential for recovery.

As yet, the treatment methods which are encouraging in animals steroids (Ducker and Hamit, 1969; Ducker and Lucas, 1974), local hypothermia produced by perfusion (Tator and Deecke, 1973), or extradural cooling (Romero-Sierra, Hansebout, Sierhuis and Lewin, 1974), normothermic perfusion of the injured cord (Tator and Deecke, 1973), myelotomy and catecholamine treatment (Osterholm, 1974) are not of established value in man.

Two reports are noteworthy. Meacham and McPherson (1973) have treated fourteen "clinically complete cases" with cooling; seven had return of function and three achieved ambulation. They did not cool any patient where the spinal cord was not anatomically intact without pulping or laceration.

Tator (1974) has treated seven complete patients with perfusion, five with hypothermic perfusion and two with normothermic perfusion. All had complete motor and sensory loss below the level of the lesion. None of Tator's patients recovered any motor function attributable to cord recovery below the level of the injury but three recovered some distal sensory function attributable to cord recovery.

For the future, within two to five years, one conclusion is highly probable: early treatment, initiated 
under four hours following acute cord injury and using one or several of the treatment techniques under research, will save from permanent complete quadriplegia or paraplegia a proportion of those individuals without complete structural disruption of the cord from the moment of injury.

New treatment techniques can only be successful when built upon a fully effective system of total management of acute cord injury which utilizes well-established knowledge now in use in paraplegic centres in various parts of the world.

Steady growth in the population of Ontario and in numbers and geographic dispersal of neurosurgeons and orthopedic surgeons has taken place in Ontario during the past 20 years. An accompaniment has been growth in the number, and increasingly wide distribution, of hospitals undertaking responsibility for the care of acute cord injury patients; smaller hospitals spread over the province have become involved.

The purpose of this paper is to document the existing system and to propose a model for the total management of patients suffering acute cord injury from the moment of injury through a lifetime follow-up.

By definition, "A model is simply an ordered set of assumptions about a complex system. It is an attempt to understand some aspect of the infinitely varied world by selecting from perceptions and past experience a set of general observations applicable to the problem at hand," (Meadows, Meadows, Randers and Behrens, 1972). In this instance the problem is the complex system needed for the total management of acute cord injuries. "Decisionmakers at every level unconsciously use mental models ..." (Meadows, Meadows, Randers and Behrens, 1972).

To develop an ordered set of assumptions, a model for total management, Table 1 , it is necessary to look at past experience; in this case all the acute cord injuries occurring in Ontario in 1969 and 1970.

(1) What is the course, the history, of all those individuals injured
TABLE 1

TOTAL MANAGEMENT

Extrication

Ambulance Service - road

Evacuation to Acute Cord Injury

Center*

Treatment in Acute Cord Injury Center*

Rehabilitation - Rehabilitation Hospital

- Rehab. Unit of General Hospital

Follow-up, lifetime.

* Acute Cord Injury Centre (ACIC) - any hospital undertaking responsibility for surgical treatment, operative or non-operative, of a patient with an acute cord injury.

in Ontario who had an acute cord injury in 1969 or 1970 ?

(2) Is the store of established clinical knowledge being applied successfully to the total management of acute cord injury patients?

(3) Does the system of total management permit the application and evaluation of new methods of treatment early after injury - within four hours?

(4) How many acute cord injuries were incomplete, though profoundly injured, following the initial application of force and became complete because of progressive or sequential injury during the hazards of total management?

(5) How many patients progressed, and even became complete, from secondary vascular changes which may in the future become preventible or reversible?

\section{Methodology of Inquiry}

In the course of this study in Ontario during 1972, 1973 and 1974, it was necessary to obtain directly from each hospital in the province a nominal roll of acute cord injuries admitted in 1969 and 1970. To ensure the legality of such an inquiry, the principal investigator and research assistant were appointed Inspectors of Hospital Records by the Government of Ontario. The cooperation and assistance of the Ontario Hospital Association and every hospital in Ontario, save one small institution, made this study possible.
Our grateful thanks go to $\mathrm{Mr}$. R. Alan Hay, executive director of the Ontario Hospital Association, and to the record librarians of the Ontario hospitals for their helpful and unfailing courtesy. The physicians and surgeons caring for these patients gave us much assistance and encouragement.

Ambulance reports were studied when available. The hospital records of every patient have been reviewed and the available data recorded on a questionnaire developed for this study. This was designed to encompass the progress of the patient from extrication, e.g. from auto wreckage or lake, to death, or the completion of primary definitive rehabilitation. Transferral of data from hospital records to the questionnaire in approximately half the cases treated in Ottawa, Sudbury, Thunder Bay, Kingston, Hamilton and London was rechecked. The questionnaires relative to many of the acute cases treated in Toronto general hospitals and to Lyndhurst Lodge Hospital cases were rechecked. In addition, each questionnaire was reviewed after completion and a personal evaluation of the case was made (E.H.B.)

The reports of all the post-mortem examinations carried out under the authority of the Coroner were made available to us, thanks to the cooperation of the Chief Coroner of Ontario, Dr. H. B. Cotnam.

Data on place of residence were obtained for all 190 survivors during the study period 1972 to 1974 , and data on their employment were obtained whenever possible. Final data from the questionnaires were then processed and analyzed with the assistance of the Queen's University Computing Centre.

\section{Incidence of Acute Cord Injuries}

Two hundred twenty-four acute cord injuries were admitted to the hospitals in Ontario in 1969 and 1970 , judging by the results of a search of nominal rolls and study of patient records supplied by general hospitals, rehabilitation hospitals, convalescent hospitals, hospitals for the chronically ill and nursing homes. Patients dead on arrival at 
the first hospital are excluded from this series.

TABLE 2

224 Acute Cord Injury Patients

\begin{tabular}{|c|c|c|c|}
\hline & $\begin{array}{c}\text { Poputation } \\
\text { Ontario }\end{array}$ & Patients & $\begin{array}{l}\text { Incidence ratc } \\
\text { per million }\end{array}$ \\
\hline 1969 & 7.5 million & 119 & 15.9 \\
\hline 1970 & 7.7 million & 105 & 13.6 \\
\hline
\end{tabular}

\section{Etiology: Accidents}

In analyzing the various causes of traumatic quadriplegia and paraplegia in Ontario in 1969 and 1970 (Table 3), road accidents take first place -97 or $43.3 \%$ - followed by industrial accidents with 40 (17.8\%). In as much as industrial accidents were calculated as falls or hits or crushes by an object at work, it should be noted that if falls at work, home or play are considered as a group $51(22 \%)$ - they are the second leading mechanism of spinal cord injury. Sports injuries rank third with $38(16.9 \%)$. Great attention must be paid to the fact that 25 out of $38(65.7 \%)$ sports accidents were caused by diving into pool, lake or river. Diving victims are almost always young men in the prime of life; 12 individuals were under 20
TABLE 3

ETIOLOGY

224 ACUTE CORD INJURIES

ONTARIO 1969 AND 1970

\begin{tabular}{|c|c|c|c|c|c|}
\hline \multirow[t]{2}{*}{ TYPE OF ACCIDENT } & \multicolumn{2}{|c|}{ QUADRIPLEGIA } & \multicolumn{2}{|c|}{ PARAPLEGIA } & \multirow[t]{2}{*}{ TOTAL } \\
\hline & complete & incomplete & complete & incomplete & \\
\hline \multicolumn{6}{|l|}{ Road Accident: } \\
\hline Motor Vehicle & 16 & 27 & 17 & 20 & \\
\hline Motorcycle & 2 & 2 & 5 & 2 & 97 \\
\hline Pedestrians & 2 & & 1 & 3 & \\
\hline \multicolumn{6}{|l|}{ Sports: } \\
\hline Diving & 7 & 17 & & 1 & \\
\hline Football & & 3 & & & 38 \\
\hline Tobogganing & & & & 4 & \\
\hline Other & & 4 & 1 & 1 & \\
\hline \multicolumn{6}{|l|}{ Industrial*: } \\
\hline Fall & & 4 & 4 & 12 & \\
\hline Hit or crushed & & & & & 40 \\
\hline by object & 4 & 2 & 5 & 9 & \\
\hline Stab Wounds: & & & & 2 & 2 \\
\hline Gun Shot Wounds: & & 2 & 4 & 1 & 7 \\
\hline Aeroplane: & & & & 2 & 2 \\
\hline \multicolumn{6}{|l|}{ Falls: } \\
\hline (Other than & & & & & \\
\hline industrial) & 8 & 13 & 4 & 6 & 31 \\
\hline Miscellaneous: & 1 & 1 & 1 & 4 & 7 \\
\hline TOTALS & 40 & 75 & 42 & 67 & 224 \\
\hline
\end{tabular}

years of age. During July and August, diving accidents rival or equal motor vehicle accidents as a cause of spinal cord injury. In this two year period, in the months of July and
Figure 3-224 Acute Spinal Cord Injuries, Ontario 1969 and 1970: Age in Years - Sex.

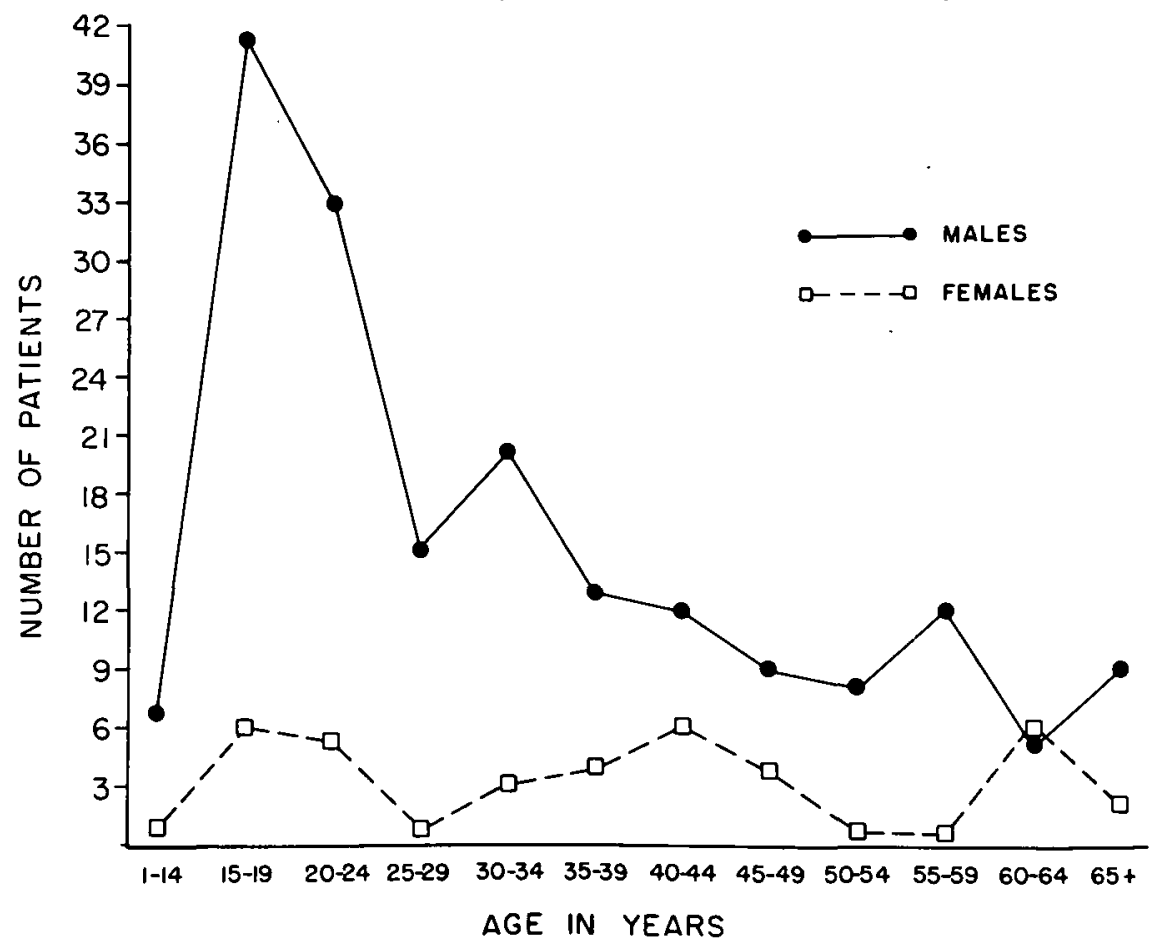

August, there were 17 cervical cord injuries from diving and 18 cord injuries at various levels from motor vehicle accidents. As in larger series, the majority of cases are male -184 of 224 patients $(82 \%)$. The incidence of spinal cord injuries by age and sex are shown in Figure 3; by month, day of the week and time of day along with the hazards of weekend driving in July and August are illustrated in Figures 4, 5 and 6.

Quadriplegic patients, complete or incomplete, have a cord injury at the first thoracic segment or above. Paraplegic patients have a cord lesion at or below the second thoracic segment.

\section{Deaths}

Of the 224 acute cord injuries occurring in 1969 and 1970,34 are known to have died by the end of 1974. Of the 34 deaths, almost half - 16- occurred during the first two weeks following injury, as shown in Figure 7.

The predominant causes of death, Table 5 , in quadriplegia are pulmonary atelectasis and pneumonitis, pulmonary edema and respiratory 
TABLE 4

34 TOTAL DEATHS

OCCURRING IN THE STUDY GROUP 1969-1974

\begin{tabular}{llcccc}
\hline & & \multicolumn{2}{c}{ DEATHS } \\
\cline { 4 - 5 } QUADRIPLEGICS: & Complete & Patients & & Total & Under 14 Days \\
& Incomplete & $\frac{75}{115}$ & & $\frac{9}{27}$ & $\frac{5}{14}$ \\
PARAPLEGICS: & Complete & 42 & & 4 & 2 \\
& Incomplete & $\frac{67}{109}$ & & $\frac{3}{7}$ & $\frac{0}{2}$ \\
\hline
\end{tabular}

failure of central origin. Pure diaphragmatic respiration is a fragile life-line.

Fourteen of the sixteen deaths occurring in the first two weeks following acute cord injury were in complete and incomplete quadriplegic patients.

The complete quadriplegic patients had the highest mortality in the first two weeks - nine deaths among 40 patients. Complete quadriplegic patients and severe incomplete quadriplegic patients remained vulnerable throughout the next five years to pulmonary complications.

To prevent and to treat pulmonary complications in the quadriplegic patient a constantly available and well-trained staff is needed, with understanding of the problems of pure diaphragmatic respiration such as the importance of assisted coughing in the prevention of atelectasis. This

Figure 4-224 Acute Spinal Cord Injuries, Ontario 1969 and 1970: Incidence by month.

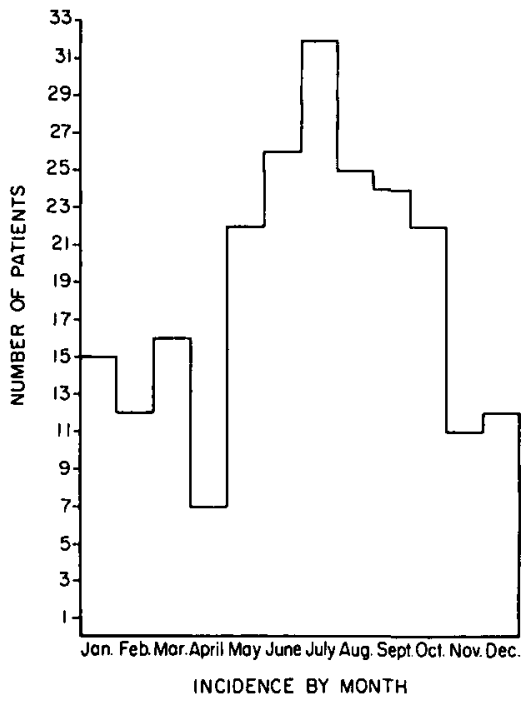

is especially important during the first weeks following injury.

In complete paraplegia, death in the early days after injury is uncommon - two among 42 cases multiple.

Table 6 shows the cause of death among complete and incomplete paraplegic patients.

\section{Geographical Distribution}

The geographical distribution of the places of injury has been established and related to the hospitals where each of the 224 patients received definitive surgical treatment, operative or non-operative, the acute cord injury center - A.C.I.C.

The number of acute cord injuries is shown in Figure 8 by county of occurrence, demonstrating the remarkable geographical scatter. For purposes of geographical orienta-

Figure 5-224 Acute Spinal Cord Injuries. Ontario 1969 and 1970: Incidence by day of week.

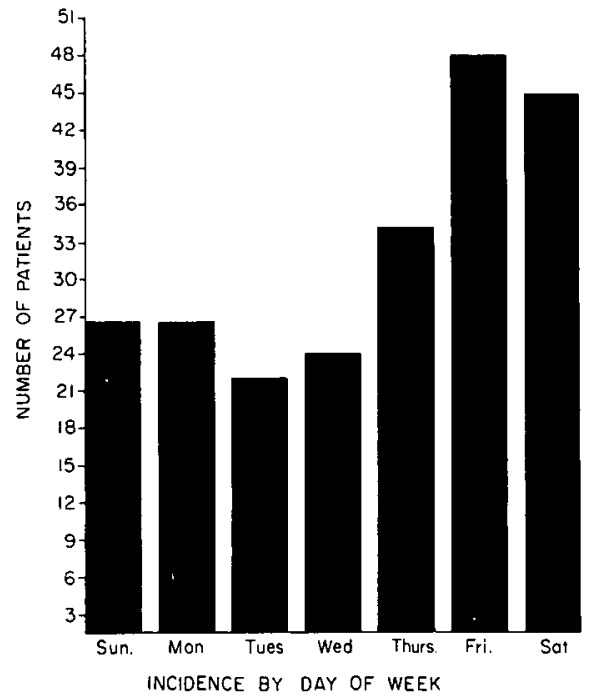
in spite of associated injuries, often
TABLE 5

27 Deaths Occurring Among 115 Quadriplegic Patients 1969 to 1974 CAUSE OF DEATH

\begin{tabular}{lr} 
Cause of death & $\begin{array}{c}\text { No. of } \\
\text { deaths }\end{array}$ \\
\hline Pneumonia; Pulmonary & \\
$\quad$ edema; Pulmonary collapse, & \\
$\quad$ Respiratory arrest & 18 \\
Pulmonary embolism & 2 \\
Cardiac failure & 2 \\
Malignant disease & 2 \\
Renal failure & 1 \\
Suicide & 1 \\
Hematemesis & 1 \\
\hline
\end{tabular}

TABLE 6

7 Deaths Occurring Among 109 Paraplegic Patients 1969-1974

CAUSE OF DEATH

\begin{tabular}{lc} 
Cause of death & No. of deaths \\
\hline Pulmonary embolism & 2 \\
Renal failure & 2 \\
Pulmonary edema & 1 \\
Fat embolism & 1 \\
Malignant disease & 1 \\
\hline
\end{tabular}

Figure 6-224 Acute Spinal Cord Injuries, Ontario 1969 and 1970: Incidence by time of day.

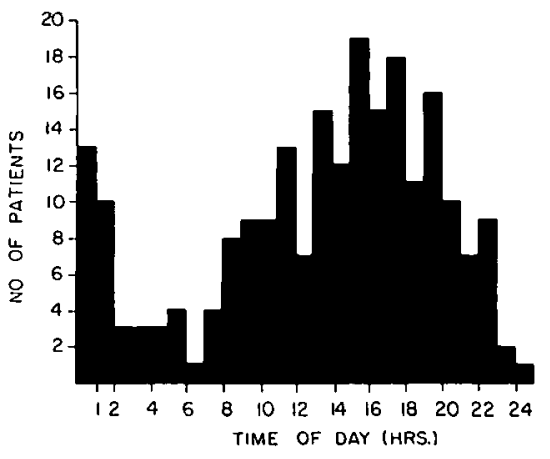

Figure 7-34 Deaths 1969 to 1974: Time of death after injury.

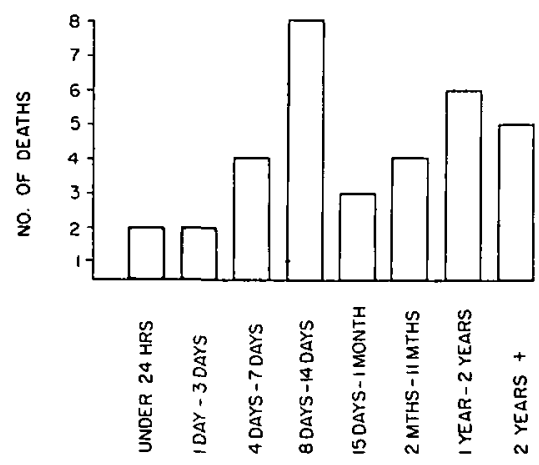




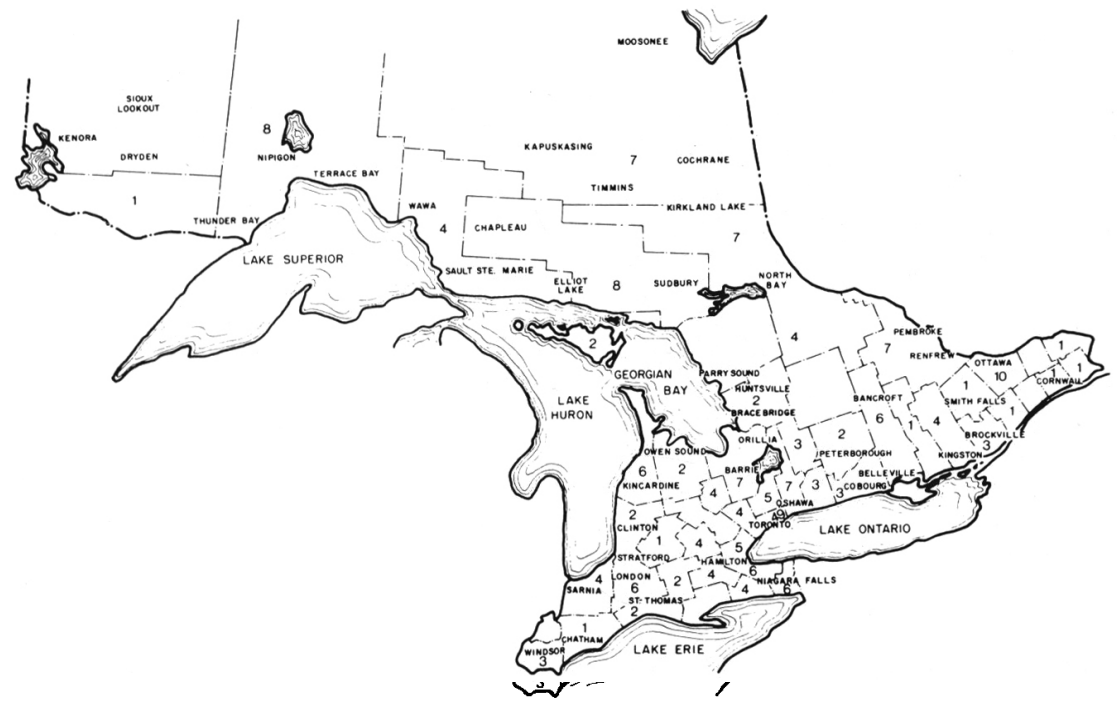

Figure 8-Distribution of 224 acute spinal cord injuries Ontario 1969 and 1970 by county. tion, the location is shown of a number of cities and towns, including the regional centers with medical schools - London, Hamilton, Toronto, Kingston and Ottawa.

Regional center hospitals are defined as those forming part of a health sciences center affiliated with a university medical school. Hospitals unaffiliated with a university faculty are defined as non-regional center hospitals. Every hospital treating definitively even one acute cord injury is serving as an acute cord injury center.

The regions follow the boundaries of the Ontario Council of Health provisional regional planning areas, 1969. Each region has a regional center based on a university health sciences complex, except Sudbury and Thunder Bay which have been treated separately. The acute cord injuries in a region have been related to the number of hospitals in the region serving as an acute cord injury center. This analysis identified a major problem. In Ontario, 51 hospitals undertook the responsibility for definitive treatment of 224 patients with acute cord injuries, complete and incomplete quadriplegic and paraplegic patients.

The seven regions (Fig. 9) have
Figure 9-Distribution of 224 acute spinal cord injuries Ontario 1969 and 1970 by region as set up by the Ontario Council of Health 1969.

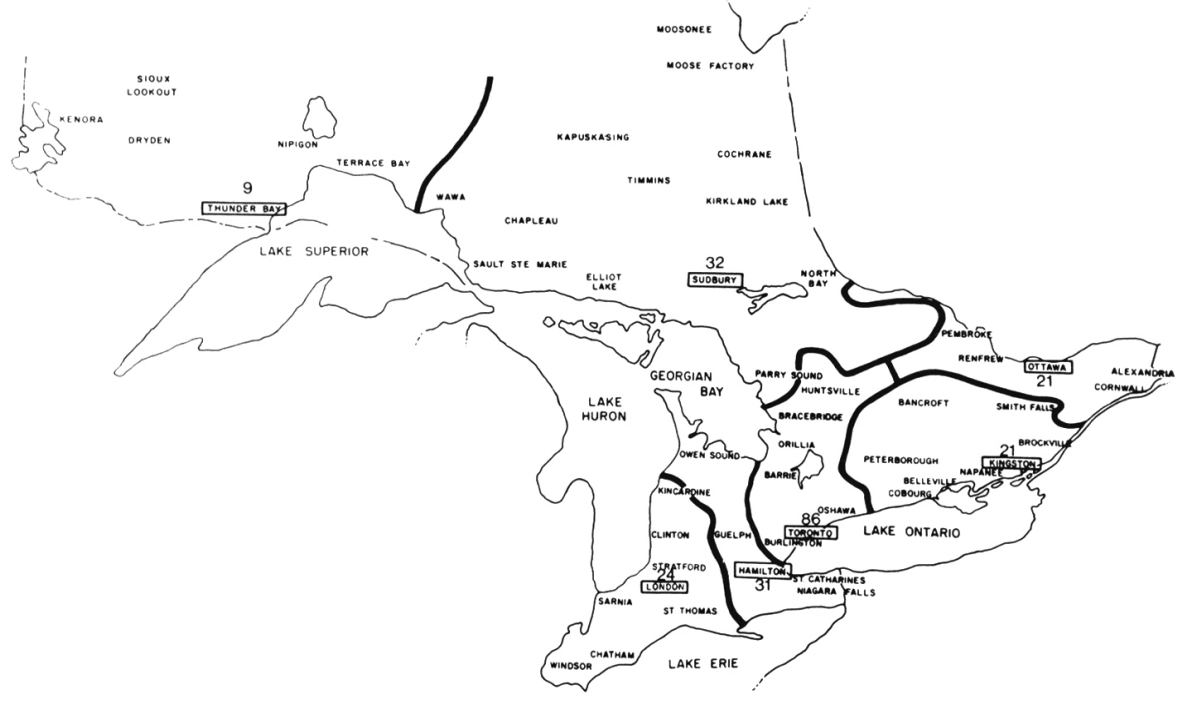

differing population densities, unique problems of terrain and climate, and variation in the size of the region. All regions save Sudbury and Thunder Bay have as a regional center a university health sciences complex with university affiliated hospitals. Thunder Bay relates specially to McMaster University, six hundred miles away. It follows that in each region the total management of acute spinal cord injuries is shaped by ecology, by the operation and availability of road and air ambulance services, by the presence or absence of regional center hospitals and their utilization, and by physicians.

The Sudbury region (Fig. 9) is large. It has long, severe winters and a scattered and low density population outside the city of Sudbury. In 1969 and 1970, 32 acute cord injuries were recorded, and 15 patients were transferred to three hospitals out of the region (Table 7).

Table 7 illustrates the widespread dispersal of patients in hospitals in the region; seventeen patients were definitively treated in eight hospitals and in the city of Sudbury, all three hospitals treated acute cord injury patients.

Thunder Bay region (Fig. 9) has a low density population beyond the limits of the city of Thunder Bay and is spread over a large area. The city of Thunder Bay is some 566 air miles

TABLE 7

SUDBURY REGION

32 Acute Spinal Cord Injuries 1969 and 1970

\begin{tabular}{cc}
\hline 3 SUDBURY & \\
HOSPITALS & PATIENTS \\
\hline A & 6 \\
B & 1 \\
C & 3
\end{tabular}

5 NON-REGIONAL

CENTER HOSPITALS

\begin{tabular}{cc}
\hline A & 1 \\
B & 3 \\
C & 1 \\
D & 1 \\
E & 1 \\
3 OUT-OF-REGION & \\
HOSPITALS & 11 \\
\hline A & 2 \\
B & 2 \\
\hline C
\end{tabular}


TABLE 8

THUNDER BAY REGION

9 Acute Spinal Cord Injuries 1969 and 1970

\begin{tabular}{ccc}
\hline $\begin{array}{c}\text { ThHNDER BAY } \\
\text { HOSPITALS }\end{array}$ & PATIENTS \\
\cline { 1 - 1 } A & 2 \\
B & 4 \\
C & 3 \\
\hline
\end{tabular}

from Toronto and 373 air miles from Winnipeg. All the nine acute cord injuries received definitive treatment in Thunder Bay and were dispersed in three different hospitals. Two patients were treated in one hospital, four in the second hospital, and three in the third hospital (Table 8).

Hamilton, Kingston, London, Ottawa and Toronto regions have variably larger and denser concentrations of people than Sudbury and Thunder Bay (Fig. 9). Transportation by road is usually easier in the southern regions than in the northern regions during winter weather. Toronto regional center hospitals had an inflow of 21 acute cord injuries from other regions, chiefly from Sudbury, and an outflow of 3 cases. The distribution of acute cord injury patients by hospital is shown in Table 9.

TABLE 9

TORONTO REGION

86 Acute Spinal Cord Injuries 1969 and 1970

\begin{tabular}{|c|c|c|c|}
\hline \multicolumn{3}{|c|}{$\begin{array}{l}\text { 6 REGIONAL } \\
\text { CENTER HOSPITALS }\end{array}$} & PATIENTS \\
\hline \multicolumn{3}{|c|}{$\mathrm{A}$} & 23 \\
\hline \multicolumn{3}{|c|}{ B } & 16 \\
\hline \multicolumn{3}{|c|}{$\mathrm{C}$} & 2 \\
\hline \multicolumn{3}{|c|}{$\bar{D}$} & 13 \\
\hline \multicolumn{3}{|c|}{$\mathrm{E}$} & 1 \\
\hline \multicolumn{3}{|c|}{$\mathrm{F}$} & 4 \\
\hline \multicolumn{3}{|c|}{$\begin{array}{l}12 \text { NON-REGIONAL } \\
\text { CENTER HOSPITALS }\end{array}$} & \\
\hline \multicolumn{3}{|c|}{ Patients } & \\
\hline A & 2 & G & 2 \\
\hline B & 4 & $\mathrm{H}$ & 1 \\
\hline $\mathrm{C}$ & 1 & I & 2 \\
\hline D & 2 & $\mathrm{~J}$ & 4 \\
\hline E & 2 & $\mathrm{~J}$ & 4 \\
\hline $\mathrm{E}$ & 3 & K & 1 \\
\hline 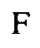 & 1 & $\mathrm{~L}$ & 1 \\
\hline \multicolumn{3}{|c|}{$\begin{array}{c}2 \text { OUT-OF-REGION } \\
\text { HOSPITALS }\end{array}$} & \\
\hline & A & & 2 \\
\hline & B & & 1 \\
\hline
\end{tabular}

In the Toronto region, a striking feature is the widespread dispersal of acute cord injury patients in both university affiliated regional center hospitals and non-regional center hospitals. In one regional center hospital, two separate surgical units undertook the responsibility for acute cord injury patients. Dispersal of patients is also evident in the Hamilton region in both regional center and non-regional center hospitals (Table 10).

TABLE 10

HAMILTON REGION

31 Acute Spinal Cord Injuries 1969 and 1970

\begin{tabular}{|c|c|}
\hline $\begin{array}{c}2 \text { REGIONAL CENTER } \\
\text { HOSPITALS }\end{array}$ & PATIENTS \\
\hline $\mathrm{A}$ & 10 \\
\hline $\mathrm{B}$ & 4 \\
\hline \multicolumn{2}{|l|}{$\begin{array}{l}6 \text { NON-REGIONAL } \\
\text { CENTER HOSPITALS }\end{array}$} \\
\hline $\mathrm{A}$ & 1 \\
\hline B & 3 \\
\hline $\mathrm{C}$ & 2 \\
\hline $\mathrm{D}$ & 1 \\
\hline $\mathrm{E}$ & 1 \\
\hline $\mathrm{F}$ & 2 \\
\hline \multicolumn{2}{|l|}{$\begin{array}{l}3 \text { OUT-OF-REGION } \\
\text { HOSPITALS }\end{array}$} \\
\hline $\mathrm{A}$ & 3 \\
\hline $\mathrm{B}$ & 2 \\
\hline $\mathrm{C}$ & 2 \\
\hline
\end{tabular}

In the Ottawa region (Fig. 9) three university affiliated regional center hospitals treated nineteen of 21 acute cord injury patients (Table 11).

TABLE 11

OTTAWA REGION

21 Acute Spinal Cord Injuries 1969 and 1970

\begin{tabular}{cc}
\hline 3 REGIONAL CENTER & \\
HOSPITALS & PATIENTS \\
\hline A & 7 \\
B & 10 \\
C & 2 \\
2 NON-REGIONAL & \\
CENTER HOSPITALS & \\
\cline { 1 - 1 } A & 1 \\
B & 1 \\
\hline
\end{tabular}

In the Kingston region (Fig. 9) dispersal of patients was conspicuous in both regional and non-regional center hospitals (Table 12).
TABLE 12

KINGSTON REGION

21 Acute Spinal Cord Injuries 1969 and 1970

\begin{tabular}{|c|c|}
\hline $\begin{array}{c}2 \text { REGIONAL CENTER } \\
\text { HOSPITALS }\end{array}$ & PATIENTS \\
\hline $\mathrm{A}$ & 9 \\
\hline B & 2 \\
\hline \multicolumn{2}{|l|}{$\begin{array}{l}3 \text { NON-REGIONAL } \\
\text { CENTER HOSPITALS }\end{array}$} \\
\hline A & 5 \\
\hline B & 1 \\
\hline $\mathrm{C}$ & 1 \\
\hline $\begin{array}{c}3 \text { OUT-OF-REGION } \\
\text { HOSPITALS }\end{array}$ & \\
\hline A & 1 \\
\hline B & 1 \\
\hline $\mathrm{C}$ & 1 \\
\hline
\end{tabular}

Twenty of 24 acute cord injury patients in the London region (Fig. 9) were treated in one regional center hospital. This record approaches most closely the model to be proposed (Table 13).

TABLE 13

LONDON REGION

24 Acute Spinal Cord Injuries 1969 and 1970

\begin{tabular}{ccc}
\hline $\begin{array}{c}\text { 2 REGIONAL } \\
\text { CENTER HOSPITALS }\end{array}$ & & PATIENTS \\
\hline A & & 20 \\
B & 1 \\
2 NON-REGIONAL & \\
CENTER HOSPITALS & \\
\cline { 1 - 2 } A & & 1 \\
B & 2 \\
\hline
\end{tabular}

The consolidated figures for the seven regions are shown in Tables 14 and 15 . This data relates to the question of how many acute cord injury patients must be treated in an acute cord injury unit in a year to ensure ongoing efficient humane care. One English colleague, Antony Jefferson, after long discussion summarized our agreement with the statement, "one a fortnight at least". This is not meant to include patients returning because of acute illness or for surgery related to their paraplegia or for other pathology; they, too, should receive their intensive care in the acute cord injury center. 
TABLE 14

REGION OF INJURY AND

REGION AND TYPE OF HOSPITAL OF TREATMENT

\begin{tabular}{|c|c|c|c|c|c|c|c|c|c|}
\hline \multirow[b]{2}{*}{ Region } & \multirow[b]{2}{*}{ 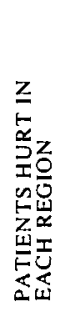 } & \multicolumn{6}{|c|}{ PATIENTS TREATED IN EACH REGION } & \multirow[b]{2}{*}{$\frac{\vec{a}}{a}$} & \multirow[b]{2}{*}{ 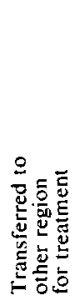 } \\
\hline & & 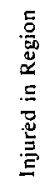 & 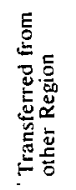 & 咅 & 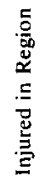 & 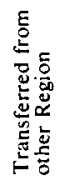 & 馬 & & \\
\hline (1) & $(2)^{*}$ & (3) & (4) & (5) & (6) & (7) & (8) & (9) & (10) \\
\hline TORONTO & 86 & 59 & 21 & 80 & 24 & 2 & 26 & 106 & 3 \\
\hline OTTAWA & 21 & 19 & 1 & 20 & 2 & - & 2 & 22 & - \\
\hline LONDON & 24 & 2] & 2 & 23 & 3 & - & 3 & 26 & - \\
\hline HAMILTON & 31 & 14 & - & 14 & 10 & 2 & 12 & 26 & 7 \\
\hline KINGSTON & 21 & 11 & - & 11 & 7 & - & 7 & 18 & 3 \\
\hline SUDBURY & 32 & 10 & - & 10 & 7 & - & 7 & 17 & 15 \\
\hline THUNDER BAY & 9 & 9 & - & 9 & - & - & - & 9 & - \\
\hline
\end{tabular}

\section{Extrication and Transportation}

to an Acute Cord Injury Center

Two problems are paramount. First, the patient with torn intervertebral disk and supraspinous ligaments and fractured or dislocated articular facets has truly an unstable spine (Fig. 10). The cord may be severely injured but quadriplegia or paraplegia may be incomplete. It is easy to finish off the cord during extrication and transportation, converting an incomplete cord injury to complete destruction of the cord. The second problem is the great size of Ontario and the geographic dispersal of the places where individuals suffer cord injury.

From the patients and their relatives, from the hospital records and from the 73 available emergency service records, we have reconstructed the routes followed by pa- tients in the course of evacuation from the scene of the accident to a hospital serving as an acute cord injury center by ambulance or other conveyance. In outline, the sequence of moves endured by patients en route to regional center and nonregional center hospitals providing definitive treatment is shown in Figure 11 .

This system of transportation of the spinal cord injury patient is sometimes referred to as a nonsystem. This is an inaccuracy. In fact, the system is that every patient is taken to the nearest hospital, regardless. This is eminently desirable for the patient with multiple injuries, surgical shock, hemorrhage or respiratory difficulties. But acute spinal cord injuries whenever possible require direct, rapid, gentle, safe transportation to a fully staffed and
TABLE 15

TREATMENT OF ACUTE CORD INJURIES

51 Regional and Non-Regional Center Hospitals

\begin{tabular}{|c|c|c|c|c|}
\hline \multirow[b]{2}{*}{ Region } & \multicolumn{2}{|c|}{ Regional Centers } & \multicolumn{2}{|c|}{ Non-Regional Centers } \\
\hline & $\begin{array}{l}\text { No. of } \\
\text { Hospitals }\end{array}$ & $\begin{array}{l}\text { No. of } \\
\text { Patients }\end{array}$ & $\begin{array}{l}\text { No. of } \\
\text { Hospitals }\end{array}$ & $\begin{array}{c}\text { No. of } \\
\text { Patients }\end{array}$ \\
\hline TORONTO & 6 & 80 & 12 & 26 \\
\hline OTTAWA & 3 & 20 & 2 & 2 \\
\hline LONDON & 2 & 23 & 2 & 3 \\
\hline HAMILTON & 2 & 14 & 6 & 12 \\
\hline KINGSTON & 2 & 11 & 3 & 7 \\
\hline SUDBURY & 3 & 10 & 5 & 7 \\
\hline THUNDER BAY & 3 & 9 & - & - \\
\hline
\end{tabular}

equipped acute cord injury center. The ideal system for the movement of an acute cord injury patient from the place of injury to a regional acute cord injury center is the responsibility of the ambulance service and is shown in Figure 12.

To retrospective analysis, first aid and transportation vary from the ideal to terrifying. Three thumbnail sketches are illustrative.

(1) Case No. 16, Ideal: A young man was "flipped" by a cow. Fortunately the patient's sister, a nurse, did not allow him to be moved prior to the arrival of the ambulance. He was then moved with traction to head and ankles, placed on a board and taken to one hospital; he was not moved from the stretcher board; he was $\mathrm{x}$-rayed and transferred to a regional acute cord injury center within $2 \frac{1}{2}$ hours of injury. He made a substantial recovery.

(2) Case No. 25, Terrifying: A bush worker was "felled by a tree" - a hoist was used to lift the tree. The patient was then carried "basket-fashion" by four workers for $1 \frac{1}{2}$ miles through the bush; he was placed semi-sitting in the back of a bus for a rough ride to the camp 20 miles away; he was transported by ambulance to hospital 20 miles away. Almost inevitably he was a complete paraplegic on arrival at hospital and without recovery. Evacuation by helicopter from the scene of the accident offered the only real chance of preserving any remaining cord function.

(3) Case No. 198, Good Samaritan: Following a motor vehicle accident on a main highway, unqualified passers-by were about to extricate the victim from the car when a physician stopped and protected the woman from dangerous movement until the arrival of the ambulance, supervised her extrication and directed her transfer to hospital. This woman had an incomplete cord injury and has recovered well.

\section{Co-Ordinated Air and \\ Highway Transportation}

During World War II, in England, the Royal Canadian Army Medical Corps sent a neurosurgical specialist, supported by ambulance and 


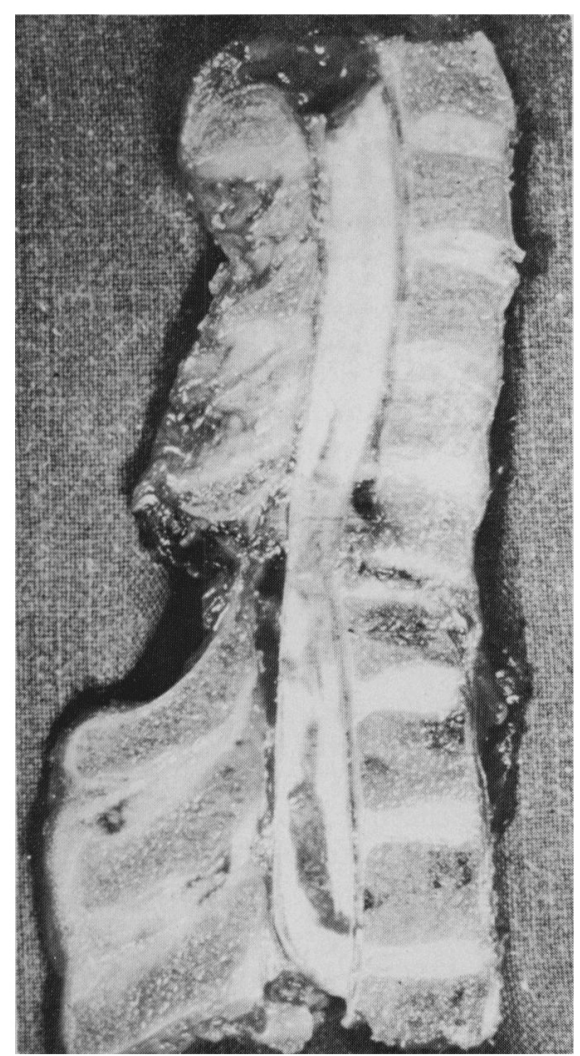

Figure 10-Cervical Spine - section in sagittal plane - demonstrating fracture-dislocation of C6-C7 with instability, intra-spinal herniation of disk and hemorrhagic contusion of the cord. stretcher bearers, to consult and accept responsibility for transferring acute cord injury patients and severe head injuries to the Canadian Neurological and Plastic Surgery Hospital. This service was available as an emergency measure by day or by night. At a later date, an air ambulance consulting and transfer service was also developed through the co-operation of the British Air Transport Auxiliary.

In 1961, Gregg (Gregg and Wilmot, 1964) of Eire described "The Flying Squad and the Paraplegic Unit", a team of a doctor, two nurses and two orderlies who were available to go immediately to any part of Ireland to collect and bring by ambulance, under supervision, any acute traumatic case of paraplegia to the National Spinal Center. Of recent years, a doctor and nurse have been flown to the patient by army helicopter within fifteen minutes of telephoning the Center. The helicopter flies back with the patient on a specially designed stretcher, together with the team. The National Medical Rehabilitation Center, Dublin, admits a predominance of cervical lesions - 109 cases, including 28 complete and 81 incomplete. Gregg

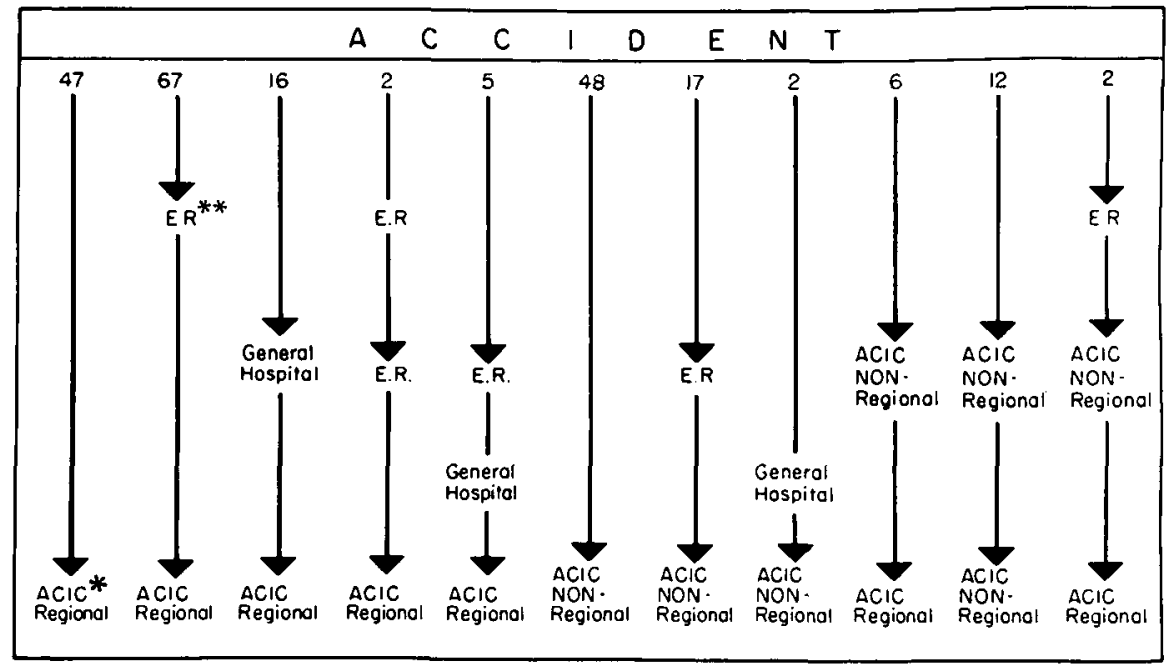

$$
\begin{aligned}
& \text { * acic - all mospitals accepting responsibilitr } \\
& \text { FOR DEFINITIVE TREATMENT OF AN ACUTE } \\
& \text { CORD INJURY ARE CLASSIFIED AS AN } \\
& \text { ACUTE CORD INJURY CENTRE. } \\
& \text { ** E.R. - treated in emergency roOM WItHOUt }
\end{aligned}
$$

Figure 11-Non-System of Evacuation - 224 Acute Spinal Cord Injuries 1969 and 1970.

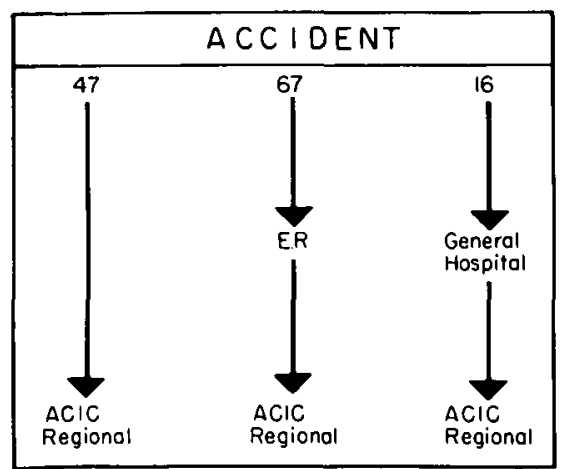

Figure 12-224 Acute Cord Injuries Model Evacuation, 130 Acute Spinal Cord Injuries from accident to regional acute cord injury center.

(1967-1968) adds, "the large figure of incomplete cervical cases is evidence of the early transfer to specialized units of many cases which previously the general hospital would have been tempted to retain." The number of incomplete cervical lesions had improved further with helicopter evacuation (Gregg, 1975).

Gillingham (1974) of Edinburgh has made the same observation, emphasizing the importance of the very early use of skull traction in cervical injuries. Hachen (1974) of Switzerland in a critical review of all acute cases transferred to the Geneva Cord Injury Unit by Swiss Air Rescue, S.R.C., reported there were no deaths during transport; the average time required for the rescue operation was 50 minutes, instead of $4 \frac{1}{2}$ hours under the former conventional system; acute cord injuries are given top priority, and due to comprehensive care before and during the flight, the patient's clinical state on arrival has already improved. A perfectly co-ordinated ground-air ambulance service has made the SRC rescue and trauma care programme one of the most efficient in the world.

Hachen (1974) also states, "Two types of stretchers have proved to be particularly helpful for patients with spinal injury - the Ferno-Washington Scoop-Stretcher and the 'multiple-lamella stretcher'. Both models totally eliminate rolling and sliding and remove the possibility of aggra- 
vation of the original injury which is always likely to occur during a lot of handling involving several transfers . . For flights over shorter distances the Laerdal Vacuum Mattress has also proved to be very helpful and convenient. It is filled with small expanded plastic balls and forms a firm mold around the patient."

The study of Peerless and Schweigel (1974) of 29 industrial injured patients in British Columbia supports the concept of the acute spinal cord injury unit.

Movement of Acute Cord Injury Patient on Arrival at Acute Cord Injury Center and in X-ray Department

With the exception of a few hospitals where the regular practice is to transfer cord injury patients from the ambulance stretcher directly to a Stryker frame, it is uncommon to find any record of the patient's movement following arrival at the emergency room. Movement is no less critical following arrival at hospital than en route; the latter is now well documented by the Emergency Services. Patients with acute spinal cord injuries deserve a record of their movement in emergency room, $\mathrm{x}$-ray department, ward and operating room.

\section{Complete or Incomplete \\ Cord Injury}

Evidence recorded concerning the completeness or incompleteness of the loss of cord function prior to arrival at the acute cord injury center established only that a lesion was incomplete, with gross sensory function or voluntary power remaining. In regional center hospitals, it often has been difficult to establish from the initial hospital clinical record that loss of cord function was "complete". The passage of time and repeated examinations have been needed to establish the completeness of spinal cord injury.

Of the 224 acute cases, 82 were judged to be complete by the clinical record made on admission to the A.C.I.C. and by the subsequent clinical course.
Acute Cord Injury Center:

Quality of Patient Care

Quality of care of the patient with an acute cord injury resulting in complete loss of cord function is measurable. Quality of care has been measured in two groups of patients: complete quadriplegia where the first segment of the cord to be involved is $\mathrm{T} 1$ segment or above, and complete paraplegia where the first segment to be involved is $\mathrm{T} 2$ or below.

In our experience recovery has been rare in patients with complete loss of cord function of 6-8 hours duration. However with early reduction and immobilization (Gallie, 1939), with gas myelography immediately following admission and early operation for intra-spinal disk or bone fragments as reported by Rossier, Berney, Rosenbaum and Hachen $(1973$, 1974), with normothermic or hypothermic perfusion of the injured cord (Romero-Sierra, Hansebout, Sierhuis, and Lewin, 1974; Tator and Deecke, 1973) and perfusion of the injured cord with gluco-corticoids (Ducker and Lucas, 1974) and myelotomy (Osterholm 1974), there is reason to anticipate that recovery will be more frequent in the future. For the preceding measures to be developed and evaluated, patients must get to the regional center in time, within four hours of injury.

The following criteria of quality of care have been studied in all patients receiving an acute cord injury in Ontario in 1969 and 1970 :

1. mortality;

2. the incidence of pressure sores;

3. the incidence of chills and fever from genito-urinary sepsis and of urinary calculi;

4. the frequency of progressive and sequential cord injury;

5. the value of operative intervention;

6. the proportion of patients who regain an independent way of life.

As the study proceeded, it became increasingly clear that significant conclusions were often difficult or impossible to establish for the patients with "incomplete" cord injury. Disability ranged from trans- ient quadriplegia recovering completely within hours save for persisting minor motor or sensory deficit, to enduring quadriplegia complete save for preservation of minor sensory function. Special emphasis has been placed, therefore, on reporting the care of patients with complete paraplegia or quadriplegia.

The mortality rate has already been reviewed. Early admission to a special regional center would improve the mortality rate of quadriplegic patients by improved intensive treatment, and particularly regarding the prevention of pulmonary complications in quadriplegic patients.

\section{Pressure Sores are Preventable}

No pressure sore developed in the first paraplegic unit in Canada The Workmen's Compensation Board Paraplegic Unit in the Toronto General Hospital started in 1946 and serving acute cord injury patients and patients requiring check-ups or admission to hospital for any reason until 1967. Lyndhurst Lodge Hospital has an enviable record healing the pressure sores acquired in other hospitals and those derived from "incidents" occuring in the course of rehabilitation, especially during a patient's weekends at home.

Dr. G. Gingras (1973), Director of the Montreal Rehabilitation Institute, records that "in 25 years of all the patients referred to me from the Montreal Neurological Institute, not one - and - I repeat - not one suffered decubiti.'

The damaging and debilitating effects upon patients of infection and loss of protein from sores, and the need for plastic surgical repair resulting from pressure sores, are well documented. In hospital, pressure sores are preventable. Coyle and Bulmer (1975) report the estimate of $\$ 5,000-\$ 7,000$ as the cost of healing a pressure sore. This is judged low for a cord injury patient.

In this 1969 and 1970 group of patients, between injury and death or completion of primary definitive rehabilitation, 70 of 224 patients are known to have had 104 pressure 
TABLE 16

INCIDENCE OF

PRESSURE SORES

\begin{tabular}{|c|c|c|c|}
\hline \multirow{5}{*}{$\begin{array}{l}\text { Complete } \\
\text { quadriplegic } \\
\text { Incomplete } \\
\text { quadriplegic } \\
\text { Complete } \\
\text { paraplegic } \\
\text { Incomplete } \\
\text { paraplegic }\end{array}$} & Patients & $\begin{array}{c}\text { Patients } \\
\text { with Pressure } \\
\text { Sores } \\
\end{array}$ & $\begin{array}{l}\text { Pressure } \\
\text { Sores } \\
\end{array}$ \\
\hline & 40 & 21 & 35 \\
\hline & 75 & 18 & 28 \\
\hline & 42 & 22 & 31 \\
\hline & 67 & 9 & 10 \\
\hline & 224 & 70 & 104 \\
\hline
\end{tabular}

sores. Complete quadriplegic and paraplegic patients are most vulnerable (Table 16).

The number of patients with complete cord lesions developing pressure sores in regional center hospitals and non-regional center hospitals demonstrates no major difference in the incidence between the two groups of hospitals (Table 17).

The evidence indicates that neither regional center hospitals nor non-regional center hospitals are staffed, organized and equipped to prevent pressure sores. The hospitals are unable to prevent (1) damage to the patient, (2) costly prolongation of treatment in hospital, and (3) in some cases the need for plastic surgical closure of sores. The nursing techniques for the prevention of pressure sores have long been well established. Mechnical aids from rippling mattresses to rocking beds and from sheep skins to commercial rubberized air mattresses converted to water beds (Coyle and Bulmer, 1975) are readily available.

The data put forward (Table 16 and 17) again establish the need for intensified nursing care to prevent pressure sores. Experience in Canada and other countries has shown that fully effective care of acute cord injury patients is accomplished best in special centers.

\section{Genito-Urinary Sepsis}

and Calculus Formation

Tidal drainage introduced by Munro in 1936, in the hands of expert staff and intelligent patients, was a major contribution to the prevention and treatment of urinary

TABLE 17

DEVELOPMENT OF PRESSURE SORES

REGIONAL \& NON-REGIONAL ACUTE CORD INJURY CENTERS COMPLETE OUADRIPLEGIC AND PARAPLEGIC PATIENTS*

\begin{tabular}{|c|c|c|c|c|c|c|}
\hline & \multicolumn{3}{|c|}{ Regional Center ACIC } & \multicolumn{3}{|c|}{ Non-Regional Center ACIC } \\
\hline & Patients & $\begin{array}{c}\text { Patients with } \\
\text { Pressure Sores } \\
\end{array}$ & $\begin{array}{c}\text { No. of } \\
\text { Presssure Sores } \\
\end{array}$ & Patients & $\begin{array}{c}\text { Patients with } \\
\text { Pressure Sores }\end{array}$ & $\begin{array}{c}\text { No. of } \\
\text { Pressure Sores }\end{array}$ \\
\hline $\begin{array}{l}\text { complete } \\
\text { quadriplegic }\end{array}$ & 28 & 11 & 11 & 16 & 7 & 8 \\
\hline $\begin{array}{l}\text { complete } \\
\text { paraplegic }\end{array}$ & 29 & 12 & 12 & 21 & 6 & 6 \\
\hline
\end{tabular}

sepsis; it was a major improvement in continuous drainage of the paralyzed bladder by an indwelling catheter.

Careful "aseptic intermittent catheterization" was first strongly advocated by Guttmann (1949, 1973) as an alternative to an indwelling urethral catheter for the treatment of the paralyzed bladder. In a large series of patients, Guttmann and Frankel (1966) reported a substantial reduction of urinary sepsis and stone formation. In a smaller, more recent series from the Royal Perth Hospital Spinal Unit in Australia, Pearman and England (1973) reported still more striking improvement, utilizing intermittent catheterization and a general ward program designed to prevent infection and cross infection. They commenced their trial of intermittent catheterization and treated all acute cord injuries from February 1969 to 30 April 1971.
Seventy-five patients in the Royal Perth Hospital were treated, 60 males and 15 females. Cases requiring catheterization for only five days or less were excluded. One patient had an ileal conduit diversion and one had an indwelling catheter. Fifty-five of the males discharged (96.5\%) and twleve of the females $(80 \%)$ were catheter free and without bacteriuria. Three quadriplegic patients had indwelling catheters (one of whom has died ).

The totals for the various techniques used for the treatment of the paralyzed bladder in each type of institution in Ontario in 1969 and 1970 has been established (Table 18).

The decision to initiate drainage of a paralyzed bladder with a Foley catheter is an important one for the urine rapidly becomes infected, in turn leading to infection of the bladder. In Ontario in 1969 and 1970, Table 19 shows the setting where a

TABLE 18

MANAGEMENT OF THE PARALYZED BLADDER* IN VARIOUS INSTITUTIONS 224 ACUTE SPINAL CORD INJURIES

\begin{tabular}{|c|c|c|c|c|c|}
\hline Type of Institution & $\begin{array}{c}\text { Crede } \\
\text { Compression } \\
\end{array}$ & $\begin{array}{c}\text { Intermittent } \\
\text { Catheter }\end{array}$ & $\begin{array}{c}\text { Foley } \\
\text { Catheter }\end{array}$ & Suprapubic & Other** \\
\hline \multicolumn{6}{|l|}{ E.R. or General } \\
\hline \multicolumn{6}{|l|}{ Hospital, en route } \\
\hline Regional Center ACIC & 4 & 8 & 137 & 2 & 17 \\
\hline \multicolumn{6}{|l|}{ Non-Regional Center } \\
\hline $\mathrm{ACIC}$ & 1 & 5 & 83 & 3 & 8 \\
\hline Rehab Hospitals & 12 & 4 & 62 & 1 & 49 \\
\hline \multicolumn{6}{|l|}{ General Hospital } \\
\hline Rehab Units & 1 & - & 45 & 3 & 30 \\
\hline TOTALS & 18 & 19 & 335 & 9 & 104 \\
\hline
\end{tabular}


TABLE 19

SETTING WHERE FOLEY CATHETER FIRST INSERTED - 200 CASES ONTARIO 1969 AND 1970

Emergency Room, en route to $\mathrm{ACIC}$

General Hospital, en route to ACIC

Regional Center ACIC

Non-Regional Center ACIC

Other

TOTAL

Foley catheter was first inserted in 200 cases.

In this series the primary decision that the paralyzed bladder should be treated by insertion of a Foley catheter was made most often, 181 of 200 cases, in the regional and nonregional center hospital accepting responsibility for the definitive treatment of the acute cord injury patient.

In the Ontario 1969 and 1970 study, between injury, and death or the completion of primary rehabilitation, the incidence of (1) genitourinary sepsis manifested by chills and fever, (2) bladder, ureteral and renal calculi, and (3) epididymitisorchitis, periurethral abscess and urethral fistula has been developed from the records. The Ontario 1969 and 1970 figures have been related to the experience of paraplegic centers in other countries.

Urinary sepsis causing chills and fever, and urinary calculi, have been established as major problems in the Ontario 1969 and 1970 series and especially in the complete quadriplegic and complete paraplegic patient. The record (Table 20) of chills and fever is a dismal one.

TABLE 20

GENITO-URINARY SEPSIS Causing "Chills \& Fever"

from Injury to Death or

Completion of Primary Rehabilitation 224 Patients

\begin{tabular}{|c|c|c|c|}
\hline & & 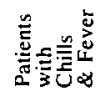 & 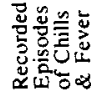 \\
\hline complete & & & \\
\hline $\begin{array}{l}\text { quadriplegia } \\
\text { incomplete }\end{array}$ & 40 & 22 & 63 \\
\hline $\begin{array}{l}\text { quadriplegia } \\
\text { complete }\end{array}$ & 75 & 26 & 59 \\
\hline $\begin{array}{l}\text { paraplegia } \\
\text { incomplete }\end{array}$ & 42 & 29 & 78 \\
\hline paraplegia & 67 & 13 & 21 \\
\hline
\end{tabular}

The incidence of epididymitisorchitis, periurethral abscess and urethral fistula is shown in Table 21 and of urinary calculus, as shown in Table 22.

TABLE 21

EPIDIDYMITIS-ORCHITIS PERIURETHRAL ABSCESS and URETHRAL FISTULA

from Injury to Death or

Completion of Primary Rehabilitation 224 Patients

\begin{tabular}{|c|c|c|c|}
\hline & 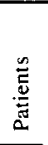 & 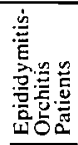 & 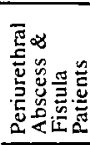 \\
\hline $\begin{array}{l}\text { complete } \\
\text { quadriplegia }\end{array}$ & 40 & 8 & 5 \\
\hline $\begin{array}{l}\text { incomplete } \\
\text { quadriplegia } \\
\text { complete }\end{array}$ & 75 & 5 & 4 \\
\hline paraplegia & 42 & 7 & 3 \\
\hline $\begin{array}{l}\text { incomplete } \\
\text { paraplegia }\end{array}$ & 67 & 8 & - \\
\hline
\end{tabular}

The record indicates the need for ongoing investigation of the treatment of the paralyzed bladder in Ontario.

\section{TABLE 22}

URINARY CALCULUS*

From Injury to Death

or Completion of Primary Rehabilitation 224 Patients

\begin{tabular}{lccc}
\hline & Patients & & $\begin{array}{c}\text { Patients } \\
\text { with Stone }\end{array}$ \\
\cline { 2 - 2 } $\begin{array}{l}\text { complete } \\
\text { quadriplegia }\end{array}$ & 40 & & 9 \\
$\begin{array}{l}\text { incomplete } \\
\text { quadriplegia }\end{array}$ & 75 & & 6 \\
$\begin{array}{l}\text { complete } \\
\text { paraplegia } \\
\text { incomplete }\end{array}$ & 42 & & 8 \\
$\begin{array}{l}\text { paraplegia } \\
\text { *bladder, ureteral and renal calculi }\end{array}$ & 67 & & 8 \\
\hline
\end{tabular}

The incidence and prevalence of calculosis in this 1969 and 1970 Ontario series of patients with cord injury compares unfavourably with the results reported of treating the paralyzed bladder by means of carefully controlled intermittent catheterization in other communities Table 23).

Pearman and England (1973) report in their 1968-1971 series of 75 patients, no instance of urinary calculus, periurethral abscess, urethral fistula, urethral diverticulum or epididymitis-orchitis had occurred to September 1971. In the final paragraph of an addendum to their book, they state "it is expected that methods of bladder management which we advocate will eliminate urinary tract infection as a major cause of morbidity and mortality in patients with spinal cord injury in Australia."

The reduction of genito-urinary sepsis and calculosis resulting from paralysis of the bladder in Ontario patients requires that (1) overdistention of the bladder en route to a regional center hospital should be controlled by careful intermittent catheterization, as needed, and supported by the local instillation of antibiotics; (2) treatment of the paralyzed bladder by intermittent catheterization must be readily and regularly available for patients in regional acute cord injury hospitals and rehabilitation hospitals or units; (3) the decision to insert a Foley catheter should be made only at the regional center or non-regional center hospital serving as an acute

\section{TABLE 23}

CALCULOSIS (After Guttmann, 1973)

\begin{tabular}{|c|c|c|c|}
\hline Author & $\begin{array}{l}\text { No. of } \\
\text { Patients }\end{array}$ & & Percentages \\
\hline Comarr, et al. (1962) & 1,507 & $8.2 \%$ & \\
\hline $\begin{array}{l}\text { Guttmann and Frankel } \\
\text { (1966): } 11 \text { years }\end{array}$ & 476 & $2.3 \%$ & $\begin{array}{l}\text { (intermittent } \\
\text { catheterization) }\end{array}$ \\
\hline Bors and Comarr (1968) & 2.322 & $10.9 \%$ & \\
\hline $\begin{array}{l}\text { Pearman and England } \\
\text { (1973): 1968-1971 }\end{array}$ & 75 & 0 & $\begin{array}{l}\text { (intermittent } \\
\text { catheterization) }\end{array}$ \\
\hline $\begin{array}{l}\text { Burr and Walsh (1974): } \\
\text { 1968-1971: 2-4 years } \\
\text { Ontario (1975): } 1969-1970^{*}\end{array}$ & $\begin{array}{l}169 \\
224\end{array}$ & $\begin{array}{l}5.8 \% \\
13.8\end{array}$ & $\begin{array}{l}(0 \text { renal }) \\
(2.2 \% \text { renal } \& \text { ureteral, } \\
11.6 \% \text { bladder })\end{array}$ \\
\hline
\end{tabular}


cord injury center; (4) the need for highly developed, early and continuing intensive urological care of the paralyzed bladder is a cogent reason for: (a) regional acute cord injury centers; (b) regional rehabilitation centers; and (c) organized lifetime follow-up for spinal cord injury patients.

\section{Progressive or Sequential Cord Injury}

The most careful search of hospital records and conversation or communication with patients and relatives have not allowed differentiation of a sequential injury from progressive cord injury, save in two or three instances. For example, in one of two cases where a patient fell from a Stryker frame, the paraplegia changed from incomplete to complete. Where doubt has existed in the mind of any reviewer of the records that the neurological deficit progressed, the case was excluded from the group of progressive or sequential cord injury patients. A transient rise and fall of the level of loss of cord function in the days following injury has not been included as a progressive or sequential injury.

Gregg in 1967 stated, "of the 146 new traumatic cases admitted by us since 1961, I know of eight cases where the paralysis started after the accident or became much more complete after the accident, in six or seven of these cases while the patient was in the general hospital."

The 32 progressive or sequential cases in Ontario in 1969 and 1970 (14.3\% of our study group) are considered (Table 24) in three groups: those occurring before medical contact, those occurring at home after initial medical assessment and those occurring in hospital.

Short summaries follow of the three cases of progressive or sequential cord injury that occurred before medical contact:

(a) Case No. 91: A 68 year old man injured by a falling tree was able to walk a short distance, sat down and a few minutes later could not move his legs.

(2) Case No. 19: A known alcoholic, a male, age 57, was found

TABLE 24

224 ACUTE SPINAL CORD INJURIES

32 Progressive or Sequential* Cord Injury with increasing neurological deficit

When neurological deficit increased

Before medical contact (home, bush, jail)

At home after initial medical assessment

In hospital (a) after fracture or fracture dislocation identified by $\mathrm{x}$-ray

(b) with fracture or fracture dislocation unidentified by $\mathrm{x}$-ray

(c) no fracture

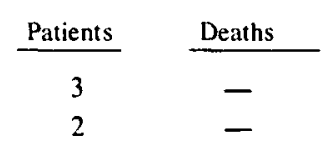

14

12

127

* sequential: occurring as a sequel of disease or injury (Webster's Third New International Dictionary Unabridged 1966).

drunk in a ditch by the police. He entered jail under his own power but the next morning had to be removed to hospital on a stretcher because of paralysis of his legs.

(3) Case No. 74: A man, age 52, fell head first down 15 stairs. He walked to the chesterfield, fell asleep and on wakening in the morning, was unable to move his arms or legs.

There were 14 patients who had progressive, increasing neurological deficit in hospital and in whom $\mathrm{x}$-ray identification of vertebral injury had been established. Twelve of these 14 patients were under active treatment for spinal cord injury and in ten cases the vertebral lesion was thoracic or lumbar.

Progressive or sequential cord injury preceded $x$-ray identification of a vertebral injury in 12 patients. This reflects a delay in clinical diagnosis sometimes associated with incomplete $x$-ray examination of the spine. Difficulties were encountered in $x$-ray examination of the cervical spine because of pain, a short neck, high shoulders, and lack of close collaboration between radiologist and clinician. In eight of the 12 cases, for a variety of reasons including multiple injuries, a request for $\mathrm{x}$-ray examination of the spine was delayed until cord injury had become increasingly manifest. Eight cases had a cervical spinal injury and four cases a thoracic, lumbar or sacral injury. None of these 12 patients was being treated for an existing or potential cord injury. There were three deaths of the 12 patients in whom acute cord injury progressed or was sequential before $\mathrm{x}$-ray diagnosis of vertebral injury; four cases occurred in regional center hospitals and eight in non-regional center hospitals.

Very early reduction and immobilization not only will prevent or minimize progressive or sequential cord injury, but evidence indicates strongly that early reduction and immobilization provides the greatest likelihood of preservation and recovery of cord function.

To achieve early and complete reduction, removal of fragments of bone or intervertebral disk from within the spinal canal and compressing the cord may be necessary.

Progressive or sequential cord injury demands expert judgment regarding the massive use of cortico steroids, the need for laminectomy to correct a pathological lesion or to permit the use of local hypothermia or normothermic perfusion of the injured cord and the consideration of utilizing myelotomy.

The frequency of painful neck injuries and back injuries without cord injury lulls physicians and roentgenologists into a sense of false security. Each cord injury is a major disaster. Acute neck or back pain, pain of nerve root origin, any disturbance of cord function - each establishes the need for immediate and fully satisfactory $x$-ray examination of the spine, including tomograms where needed. Full precautions must be taken against damage to the spinal cord by movement of the patient en route to the $x$-ray department and during $x$-ray examination. 


\section{Treatment of Spinal Cord Injury}

Operative Therapy, Spinal: For complete and incomplete cord injury, the diveristy of objectives of spinal operative treatment makes analysis of the results difficult. A spinal block, open reduction, early ambulation, intra-spinal bone or disk fragments, decompressive laminectomy, normothermic and hypothermic cord perfusion, and instability of the spine include most of the recorded reasons for operations. One hundred thirty-four patients of the group of 224 cases of acute cord injuries had spinal operative intervention, in all, 142 spinal operations. Five of the eight patients who had two operations had both a laminectomy and an anterior intervertebral discoidectomy and fusion.

The timing and variety of operative procedures, as shown in Table 25 , illustrate the need for renewed study of the rationale of spinal surgical measures in the management of acute cord injuries.

Forty-seven cases were judged by the records to have had complete loss of cord function at the time of operation; 22 were quadriplegic and 25 were paraplegic patients. In 4 cases, recovery of cord function followed upon (1) skull traction, laminectomy and hypothermia; (2) trans-thoracic removal of intraspinal fragment of disk; (3) laminectomy and removal of intra-spinal, disk, 34 hours after injury and fusion after 35 days; (4) skull traction with reduction within 2 hours, anterior fusion after 17 days.

(1) Case No. 5: An 18 year old male, injured in a diving accident, had immediately a complete quadriplegia below cervical 6 segment. Skull traction with tongs, laminectomy and hypothermic perfusion of the cord four hours after injury was followed by recovery of sensation from T-2 to T-12 dermatomes on one side.

(2) Case No. 128: A 25 year old man with a complete paraplegia at T- 10 caused by a motor vehicle accident had a trans-thoracic removal of part of the bodies of the 7th and 8 th thoracic vertebrae. Sequestrated disk fragments were removed from the intervertebral space and from the spinal canal to the right of the cord. The only recovery was the return of some sensation in the right upper thigh.

(3) Case No. 129: A 30 year old male received a direct injury from a falling tree, with a complete paraplegia at T-6. Laminectomy and removal of an intra-spinal sequestrated fragment of disk was carried out some 34 hours after injury. Internal fixation and fusion of the thoracic spine from $T-3$ to $T-9$ was done 35 days after injury. At the time of last information, he was able to walk with two canes and he was employed.

(4) Case No. 86: A male, age 18, was described unequivocally as completely quadriplegic below C-6 following a motor vehicle accident; extrication and transfer to a stretcher was careful and controlled. The patient's head was immobilized by sandbags on the ambulance stretcher; within an hour he was transported directly to a regional center hospital, fully equipped and staffed to care for acute spinal cord injuries. In hospital, he was transferred directly from the ambulance stretcher to the Stryker frame. Skull tong traction was started within two hours after injury and very early reduction achieved. Improvement of power and sensation started within a few days of admission to hospital. Seventeen days following injury, an anterior spinal fusion was done bet-

TABLE 25

OPERATIVE AND NON-OPERATIVE TREATMENTS BY TIME AFTER INJURY

\begin{tabular}{|c|c|c|c|c|c|c|c|c|}
\hline \multirow[t]{2}{*}{ TREATMENTS } & \multicolumn{8}{|c|}{ TIME AFTER INJURY } \\
\hline & $\begin{array}{c}\text { Under } 4 \\
\text { hours }\end{array}$ & $\begin{array}{l}4-8 \\
\text { hrs. }\end{array}$ & $\begin{array}{l}9-24 \\
\text { hrs. }\end{array}$ & $\begin{array}{c}1-7 \\
\text { days }\end{array}$ & $\begin{array}{l}8-30 \\
\text { days }\end{array}$ & $\begin{array}{l}3 !-90 \\
\text { days }\end{array}$ & $\begin{array}{l}y i+ \\
\text { days }\end{array}$ & $\begin{array}{l}\text { Day of Injury } \\
\text { Hour Unknown }\end{array}$ \\
\hline 1. Tongs & 3 & 2 & 1 & 15 & 5 & & & 54 \\
\hline 2. Myelogram & & & $i$ & 20 & 15 & 5 & 2 & 12 \\
\hline 3. Tracheostomy & 2 & & 1 & 6 & 1 & 1 & 1 & 3 \\
\hline 4. Steroids started & 11 & 17 & 16 & 13 & 5 & & & \\
\hline 5. Laminectomy & 4 & 16 & 6 & 8 & 6 & 4 & 2 & \\
\hline 6. Anterior fusion & & 2 & 1 & 5 & 15 & 6 & 2 & \\
\hline $\begin{array}{l}\text { 7. Posterior } \\
\text { fixation/fusion }\end{array}$ & & 1 & & & 5 & 7 & & \\
\hline $\begin{array}{l}\text { 8. Open reduction, } \\
\text { posterior }\end{array}$ & & & & & & & & \\
\hline fixation/fusion & & 2 & & 2 & 4 & 1 & & \\
\hline $\begin{array}{l}\text { 9. Open reduction, } \\
\text { laminectomy, } \\
\text { internal fixation/ } \\
\text { fusion }\end{array}$ & 7 & 12 & 11 & 4 & 7 & 1 & & \\
\hline
\end{tabular}

ween $\mathrm{C}-6$ and $\mathrm{C}-7$ vertebrae. He is living at home, leading a wheel-chair life.

In this group of 47 cases of comtreatment has been without value in relation to the recovery of cord function, save in the four preceding cases; in one case hypothermic perfusion was utilized; removal of intra-spinal disk fragments was carried out in two cases. High quality treatment within 4 hours of injury would increase substantially the frequency and extent of recovery of cord function.

The evaluation of spinal surgery has not been accomplished in cases of incomplete paraplegia and quadriplegia. The two major reasons are the potential for recovery of the incomplete cord injury without spinal surgery, and the fact that the operative and clinical records were not designed for research analysis.

The following principles are supported regarding spinal operative therapy relating to acute cord injuries:

Reduction and Immobilization: Very early reduction and immobilization of an unstable spine is essential to minimize cord injury and maximize potential recovery. Reduction includes removal of a fragment of bone or disk in the spinal canal and impinging on the cord, by laminectomy or by the anterior intervertebral approach. From time to time plete cord injury spinal operative 
in cervical and thoraco-lumbar spinal injuries, open operative reduction may be needed to obtain early reduction of a fracture dislocation and to prevent added injury to cord and/or cauda equina by hyperextension.

Laminectomy is an essential therapeutic aid for purposes of completing reduction by removal of fragments of bone or disk in the spinal canal and impinging on the cord, or to allow treatment for a specific pathological condition such as an extra-dural hematoma or for treatment by hypothermia. The decision to carry out a laminectomy should be the responsibility of a neurosurgeon working with a regional acute cord injury center who has a continuing commitment and responsibility for the treatment of patients with spinal cord injury. Otherwise, decompressive laminectomy has no place, in our view, in the treatment of acute cord injury. Early anterior cervical intervertebral discoidectomy and fusion should be reserved for those cases where the clinical, laboratory and $\mathrm{x}$-ray findings support the presence of disk fragments in the spinal canal and affecting the cord.

Stabilization of the spine: Early surgery for stabilization of the spine with a major cord injury, complete or incomplete, is uncommonly indicated. We are in agreement with Jackson (in press, 1975), "Early fusion or stabilization for gross instability would be necessary only in those few instances where conservative measures cannot be adequately carried out due to other injuries, such as severe chest problems, burns or multiple extremity injuries." Where open reduction is required, stabilization is a natural accompaniment.

\section{Rehabilitation: Costs: Status} of Patients at Last

Information 1969-1974

Remarkable gains in the quality of life of "paraplegics" result from achieving successful rehabilitation, from living at home and from a productive occupation. The financial savings are also remarkable.

In Canada the achievement of re- habilitation by quadriplegic and paraplegic patients treated at Lyndhurst since 1945 is being reported fully by Jousse and his co-workers, Breithaupt, Geisler and WynneJones (1975). Of the 1521 patients reaching Lyndhurst, 91\% have been restored to their homes and over half became productively employed, including students and housewives. This is the record of a pioneering program of high human endeavour extending over thirty years.

As with the treatment of acute cord injuries in Ontario in 1969 and 1970, rehabilitation programs for cord injury patients were provided by hospitals scattered throughout the province. One hundred and forty-four patients were admitted to a hospital or rehabilitation unit for rehabilitation; 82 of these patients were treated at Lyndhurst Lodge Hospital admitted from many hospitals serving as acute cord injury centers and from other rehabilitation units; 84 of these patients undertook programs of rehabilitation in a variety of regional and non-regional center hospitals, including some transferred from Lyndhurst. Eighty patients were not admitted as an inpatient to a rehabilitation hospital or unit in Ontario (Table 26).

Five complete quadriplegic and six complete paraplegic patients undertook rehabilitation programs in two or more centers. The patients with complete lesions were transferred to Lyndhurst more than twice as often as away from Lyndhurst to other rehabilitation units.

The variability of the disability and of the potential for recovery of cord function in cases of incomplete
TABLE 26

224 ACUTE

SPINAL CORD INJURIES

80 Patients who were Not Admitted

To Rehabilitation Hospital or Unit in Ontario

Transferred to other

province or country

4

Died in A.C.I.C.

Treated as out-patients

No rehabilitation therapy

Transferred from A.C.I.C.

to Chronic Hospital

injury makes rehabilitation needs and programs difficult to evaluate in this group. The length of stay in the various types of rehabilitation facilities has been established.

The total hospital days and cost of treatment in a rehabilitation hospital or unit have been worked out for the total group of 144 patients (Table 27).

The average length of stay and cost of treatment in a rehabilitation hospital or unit has been worked out for the group of 26 complete quadriplegic patients (Table 28) and for the 35 complete paraplegic patients (Table 29). The data shows that the severely disabled quadriplegic patients, with two exceptions, were treated at Lyndhurst and in regional center hospital rehabilitation units.

Data concerning incomplete quadriplegic and paraplegic patients is shown in Tables 30 and 31 . The wide variability of the severity of injury again creates major difficulties because of the wide range of disability. Patients with disability so severe as to be the equivalent of a complete cord injury are included as well as patients with lesser disability.

TABLE 27

COST OF REHABILITATION BY TYPE OF FACILITY IN ONTARIO 144 PATIENTS*

\begin{tabular}{|c|c|c|c|c|}
\hline & Patients & $\begin{array}{c}\text { Patient } \\
\text { Days }\end{array}$ & & Charges \\
\hline Lyndhurst Lodge Hospital & 82 & 20,950 & $\$$ & $838,964.97$ \\
\hline Ontario Crippled Children's Center & 5 & 1,013 & & $56,884.63$ \\
\hline Regional Centre Hospital & 49 & 9,134 & & $546,490.13$ \\
\hline \multirow[t]{2}{*}{ Non-Regional Centre Hospital } & 30 & 4.069 & & $140,519.54$ \\
\hline & & 35,166 & & $, 582,859.27$ \\
\hline
\end{tabular}

* The 144 patients involved in this table include 123 patients who were treated in one rehabilitation hospital or unit, 20 who were treated in two, and one who was treated in three, totalling the " 166 " patients listed. 
TABLE 28

COST OF REHABILITATION BY TYPE OF FACILITY IN ONTARIO 26 COMPLETE QUADRIPLEGIC PATIENTS*

\begin{tabular}{|c|c|c|c|c|c|c|}
\hline & Patients & $\begin{array}{c}\text { Patient } \\
\text { Days }\end{array}$ & $\begin{array}{c}\text { Average } \\
\text { Length of } \\
\text { Stay }\end{array}$ & $\begin{array}{c}\text { Average } \\
\text { Cost Per } \\
\text { Day } \\
\end{array}$ & $\begin{array}{l}\text { Cost Per } \\
\text { Patient }\end{array}$ & $\begin{array}{c}\text { Total } \\
\text { Charges }\end{array}$ \\
\hline Lyndhurst Lodge Hospital & $16++$ & 5,615 & 350.9 & $\$ 41.22$ & $\$ 14,642.88$ & $\$ 234,286.08$ \\
\hline Ontario Crippled Children's Center & $2+$ & 455 & 227.5 & 56.97 & $12,962.22$ & $25,924.45$ \\
\hline Regional Center Hospital & $12+$ & 3,243 & 270.2 & 65.25 & $17,634.21$ & $211,610.50$ \\
\hline \multirow[t]{2}{*}{ Non-Regional Center Hospital } & $2+$ & 629 & 314.5 & 35.20 & $11,071.64$ & $22,143.28$ \\
\hline & & 9,942 & & & & $\$ 493,964.31$ \\
\hline \multicolumn{7}{|c|}{$\begin{array}{l}\text { * The } 26 \text { patients involved in this table include } 21 \text { patients who were treated in one rehabilitation hospital or unit, } 4 \text { who were treated in two, and one who was treate } \\
\text { in three, totalling the " } 32 \text { " patients listed. }\end{array}$} \\
\hline \multicolumn{7}{|c|}{ + One patient was transferred to Lyndhurst Lodge Hospital. } \\
\hline
\end{tabular}

TABLE 29

COST OF REHABILITATION BY TYPE OF FACILITY IN ONTARIO 35 COMPLETE PARAPLEGIC PATIENTS*

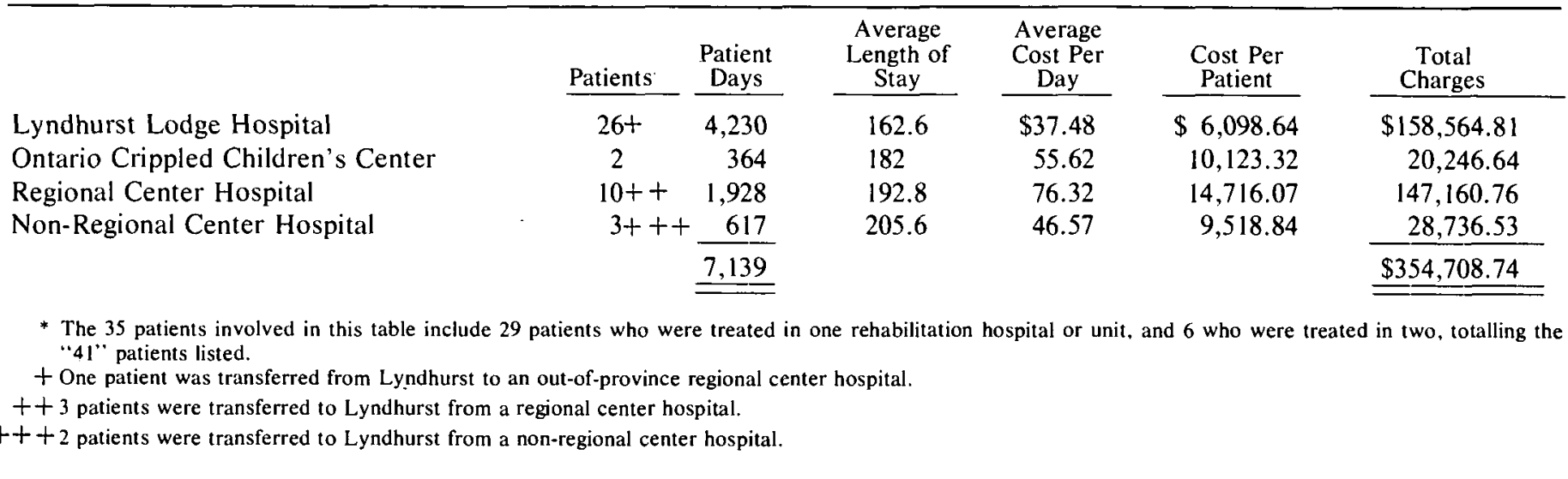

TABLE 30

COST OF REHABILITATION BY TYPE OF FACILITY IN ONTARIO 38 INCOMPLETE QUADRIPLEGIC PATIENTS*

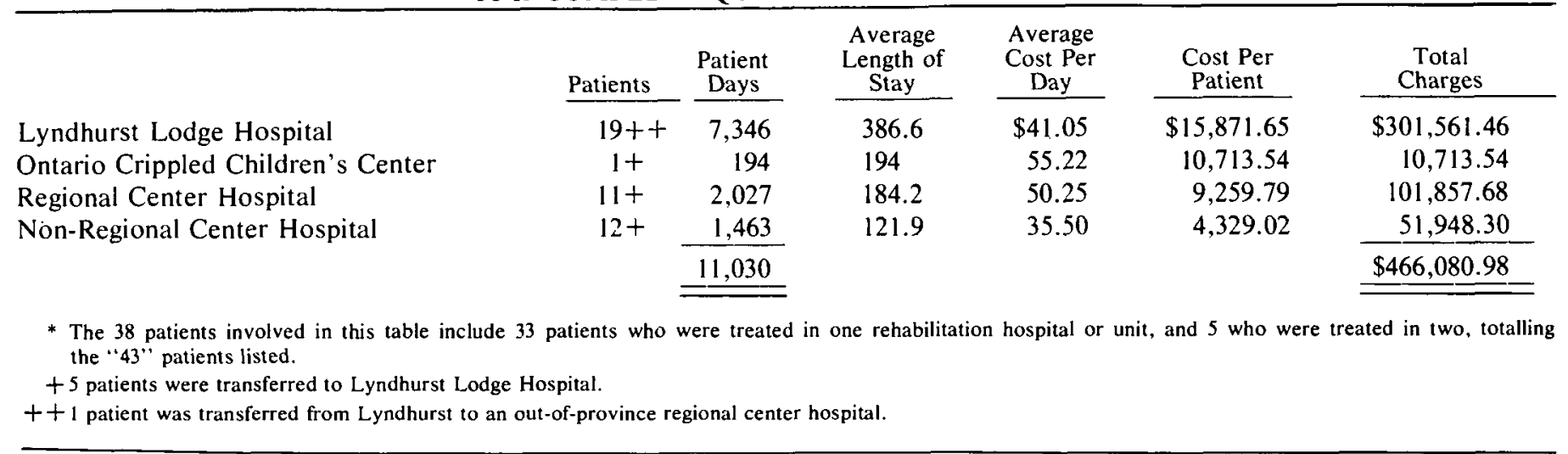


TABLE 31

COST OF REHABILITATION BY TYPE OF FACILITY IN ONTARIO 45 INCOMPLETE PARAPLEGIC PATIENTS*

Lyndhurst Lodge Hospital

Regional Center Hospital

Non-Regional Center Hospital

\begin{tabular}{|c|c|}
\hline Patients & $\begin{array}{c}\text { Patient } \\
\text { Days }\end{array}$ \\
\hline $21+$ & 3.759 \\
\hline 16 & 1,936 \\
\hline \multirow[t]{2}{*}{13} & 1,364 \\
\hline & 7,059 \\
\hline
\end{tabular}

\begin{tabular}{c}
$\begin{array}{c}\text { Average } \\
\text { Cost Per } \\
\text { Day }\end{array}$ \\
\hline$\$ 38.45$ \\
44.34 \\
27.83
\end{tabular}

\begin{tabular}{r}
$\begin{array}{c}\text { Cost Per } \\
\text { Patient }\end{array}$ \\
\hline$\$ 6,883.46$ \\
$5,366.32$ \\
$2,920.58$
\end{tabular}

$\begin{array}{r}\text { Total } \\ \text { Charges } \\ \hline \$ 144,552.62 \\ 85,861.19 \\ 37.967 .59 \\ \hline \$ 268,381.40 \\ \hline \hline\end{array}$

* The 45 patients involved in this table include 40 patients who were treated in one rehabilitation hospital or unit, and 5 who were treated in two, totalling the " 50 " patients listed.

+ One patient was transferred from Lyndhurst to a regional hospital.

Two patients were transferred to Lyndhurst from a non-regional center hospital.

Twelve of the 38 incomplete quadriplegic patients were treated in non-regional rehabilitation centers in contrast to two of 26 complete quadriplegic patients (Table 30 and 28 ). A similar situation exists with incomplete paraplegic patients for thirteen of 45 patients were treated in nonregional center hospitals and only three of the 35 complete paraplegic patients (Tables 31 and 29).

It will be noted that for patients in Lyndhurst Lodge Hospital the average cost per patient for complete quadriplegic patients was a little lower than for incomplete quadriplegic patients and similarly was a little lower for complete paraplegic patients than for incomplete paraplegic patients. This picture differs from that obtained in the regional and non-regional center hospital rehabilitation units (Tables 28, 29, 30 and $31)$ where the cost of treating complete quadriplegic and paraplegic patients was greater than the cost for incomplete cases.
There are two contributory factors in these differences: (1) the most severely disabled incomplete quadriplegic and paraplegic patients tended to gravitate to Lyndhurst Lodge Hospital rather than to the other rehabilitation units; (2) in many instances these severely disabled incomplete quadriplegic and paraplegic patients in Lyndhurst Lodge Hospital showed a slowly developing but greater rehabilitation potential than complete quadriplegic and paraplegic patients; some were therefore kept under treatment for long periods. In contrast, in other rehabilitation units, incomplete quadriplegic and paraplegic patients stayed a much shorter time on the average than complete quadriplegic and paraplegic patients; they were probably substantially less disabled.

\section{STATUS OF PATIENTS}

AT LAST INFORMATION

At the close of the year 1974 there were 190 survivors of the 224 pa- tients who in 1969 and 1970 had an acute spinal cord injury with complete or incomplete, major or minor, loss of spinal cord function (Table 32).

TABLE 32

190 SURVIVORS 1974

STATUS OF PATIENT

At Last Information +: Residence

Living outside of

Hospital

Nursing home

Extended hospital care

Chronic hospital

Other institution

+ December 1974

The status of the 190 survivors at last information has been related to the level and completeness of the lesion, place of residence and employment (Table 33). Of the 190 survivors, $86 \%$ are living at home and $64 \%$ are employed. It must be repeated that incomplete quadriplegic

TABLE 33

190 SURVIVORS

STATUS OF PATIENT AT LAST INFORMATION+ RESIDENCE AND EMPLOYMENT

Complete quadriplegic patients

Incomplete quadriplegic patients

Complete paraplegic patients

Incomplete paraplegic patients

$\begin{array}{cccc}\frac{\text { Total }}{22} & & \text { Hospital* } & \text { Home } \\ & 11 & & 11 \\ 66 & 7 & 59 \\ 38 & 5 & 33 \\ 64 & 2 & 62\end{array}$

+ December 1974

* Hospital - chronic hospital, nursing home, extendicare

** Employed - student, housewife, gainfully employed
EMPLOYED**

\begin{tabular}{|c|c|c|c|}
\hline Total & Student & Housewife & Gainfully Employed \\
\hline 6 & 4 & 0 & 2 \\
\hline 47 & 8 & 4 & 35 \\
\hline 19 & 1 & 3 & 15 \\
\hline 50 & 10 & 6 & 34 \\
\hline
\end{tabular}


and paraplegic patients vary greatly in the severity of neurological deficit. Patients are included who did not require a rehabilitation program in hospital as well as patients living in institutions.

The status at last information of the patients who had a rehabilitation program as an in-patient in Ontario, their survival, place of residence and employment is shown in Table 34. Of the 133 survivors, $84 \%$ are living at home and $59 \%$ are employed. These individuals had to change their way of life and had major problems in rehabilitation. The independent way of life of a "paraplegic" patient living at home is a major personal triumph for each individual, magnified by employment. For the province of Ontario, each day an individual quadriplegic or paraplegic patient is at home saves the cost of a hospital bed.
224 Acute Spinal Cord Injuries

Total Hospital Costs 1969-1973 from Injury to Death, or Completion of Primary Rehabilitation - Projected Hospital Costs 1974-1978

In this Ontario group of acute cord injury patients, 1969 and 1970 , the total actual costs of hospitalization (Table 35) have been established for the years 1969-1973. The costs of physicians' services are not included.

Complete and incomplete paraplegic patients concluded their primary definitive rehabilitation in 1972 , save for three complete and three incomplete quadriplegic patients, who were under active treatment in 1973 also.

To make current the financial cost of a comparable series of 224 acute spinal cord injury patients occurring in 1974 and 1975 , the percentage rate of increase in costs has been estimated as follows: (Table 35) $20 \%$ has been used for 1974 and $10 \%$ for the years 1975 to 1978 inclusive. These figures, decided upon by the authors after consultation with the Ministry of Health of Ontario, are in the middle range and are below the highest estimates with which we were provided.

The 1969-1973 total hospital costs and the 1974-1978 projected costs are shown in Tables 36 and 37 for complete quadriplegic and paraplegic patients.

The total hospital costs, 1969 to 1973, for 75 incomplete quadriplegic patients was $\$ 874,801$. The total projected costs for a 1974 to 1978 series of patients is $\$ 1,833,541$; for 67 incomplete paraplegic patients the 1969 to 1973 total was $\$ 509,409$; and projected to 1974 to 1978 , the total was $\$ 1,225,402$.

TABLE 34

QUADRIPLEGIC AND PARAPLEGIC PATIENTS

144 ADMITTED TO A REHABILITATION HOSPITAL OR UNIT

AT LAST INFORMATION +: SURVIVAL, RESIDENCE, EMPLOYMENT

Complete quadriplegic patients Incomplete quadriplegic patients Complete paraplegic patients Incomplete paraplegic patients

\begin{tabular}{|c|c|c|c|}
\hline Total & Deaths ++ & Hospital* & Home \\
\hline 26 & 6 & 10 & 10 \\
\hline 38 & 2 & 5 & 31 \\
\hline 35 & 1 & 3 & 31 \\
\hline 45 & 2 & 2 & 41 \\
\hline
\end{tabular}

\footnotetext{
+ December 1974
}

++ Deaths - following completion of primary rehabilitation

* Hospital - chronic hospital, nursing home, extendicare

TABLE 35

TOTAL HOSPITAL COSTS 1969-1973

224 ACUTE SPINAL CORD INJURIES FROM INJURY TO DEATH, OR COMPLETION OF PRIMARY REHABILITATION

\begin{tabular}{|c|c|c|c|c|c|}
\hline & $\begin{array}{c}\text { Patient } \\
\text { Days }\end{array}$ & Injured 1969 and 1970 & \multicolumn{3}{|c|}{ If Injured 1974 and 1975} \\
\hline & & Actual Costs & & $\begin{array}{c}\text { Estimated } \\
\% \text { Increase* }\end{array}$ & $\begin{array}{c}\text { Estimated } \\
\text { Costs }\end{array}$ \\
\hline 1969 & 14,124 & $\$ 714,149$ & 1974 & $20 \%$ & $\$ 1,307,459$ \\
\hline 1970 & 23,823 & $1,254,385$ & 1975 & $10 \%$ & $2,425,181$ \\
\hline 1971 & 13,879 & 654,534 & 1976 & $10 \%$ & $1,554,170$ \\
\hline 1972 & 3,746 & 174,512 & 1977 & $10 \%$ & 461,133 \\
\hline \multirow[t]{2}{*}{1973} & 924 & 48,141 & 1978 & $10 \%$ & 125,110 \\
\hline & & $\$ 2,845,721$ & & & $\$ 5,873,053$ \\
\hline
\end{tabular}

* From 1974 to 1978 the estimated \% rate of increase in hospital costs has been projected after consultation with the Ontario Ministry of Health. 


\section{CONCLUSIONS}

1. Substantial as is the merit of the existing care, province wide, of patients with acute cord injury, there is great need for development of an improved system of total management of patients with acute spinal cord injuries, and for prevention of spinal injuries.

2. A new model is needed for the care of acute cord injuries.

\section{New Model}

3. Only regional acute cord injury centers, relating to geographical and population needs, specially equipped and staffed, should accept the responsibility for definitive care of acute quadriplegic and paraplegic patients (complete or incomplete), unless the emergency nature of the patient's multiple injuries or general condition dictates otherwise.

4. All regional acute cord injury centers and paraplegic rehabilitation centers (hospitals or hospital units) should be affiliated with a university health sciences complex even where geography is an obstacle.

5. Regional acute cord injury centers must be developed and be recognized by doctors and hospitals.

6. Development is required of new methods of treatment to be applied within four hours of injury.
7. A regional acute cord injury center requires the admission of a minimum of 20-25 acute cord injury patients each year. Additionally, an equal or greater number of readmissions of paraplegic and quadriplegic patients will be admitted for recheck, requiring surgery, or with an acute medical illness.

8. Unification or close integration must be achieved of regional acute cord injury centers and regional rehabilitation hospitals or hospital units.

9. One physician, a paraplegist, must be responsible for the overall care and management of the quadriplegic or paraplegic

TABLE 36

TOTAL HOSPITAL COSTS

40 COMPLETE QUADRIPLEGIC PATIENTS FROM INJURY TO DEATH, OR COMPLETION OF PRIMARY REHABILITATION

\begin{tabular}{|c|c|c|c|c|c|c|}
\hline \multirow[b]{3}{*}{1969} & \multirow{3}{*}{$\begin{array}{c}\begin{array}{c}\text { Patient } \\
\text { Days }\end{array} \\
1,867\end{array}$} & \multirow{3}{*}{$\frac{\text { Injured } 1969 \text { and } 1970}{\frac{\text { Actual Costs }}{\$ 104,865}}$} & \multicolumn{4}{|c|}{ If Injured 1974 and 1975} \\
\hline & & & \multicolumn{2}{|c|}{$\begin{array}{c}\text { Estimated } \\
\% \text { Increase }\end{array}$} & \multicolumn{2}{|c|}{$\begin{array}{c}\text { Estimated } \\
\text { Costs }\end{array}$} \\
\hline & & & 1974 & $20 \%$ & & 172,828 \\
\hline 1970 & 5,697 & 310,502 & 1975 & $10 \%$ & & 579.955 \\
\hline 1971 & 5,255 & 232,392 & 1976 & $10 \%$ & & 588,035 \\
\hline 1972 & 1,785 & 69,325 & 1977 & $10 \%$ & & 219,734 \\
\hline \multirow[t]{2}{*}{1973} & 451 & 20,470 & 1978 & $10 \%$ & & 61,065 \\
\hline & & $\$ 737,554$ & & & & .621 .617 \\
\hline
\end{tabular}

TABLE 37

TOTAL HOSPITAL COSTS

42 COMPLETE PARAPLEGIC PATIENTS FROM INJURY TO DEATH, OR COMPLETION OF PRIMARY REHABILITATION

\begin{tabular}{|c|c|c|c|c|c|c|}
\hline & \multirow[t]{2}{*}{$\begin{array}{c}\text { Patient } \\
\text { Days }\end{array}$} & \multirow{2}{*}{$\frac{\text { Injured } 1969 \text { and } 1970}{\text { Actual Costs }}$} & \multicolumn{4}{|c|}{ If Injured 1974 and 1975} \\
\hline & & & & $\begin{array}{c}\text { Estimated } \\
\text { \% Increase* } \\
\end{array}$ & & $\begin{array}{l}\text { stimated } \\
\text { Costs }\end{array}$ \\
\hline 1969 & 3,198 & $\$ 168,089$ & 1974 & $20 \%$ & & 296,039 \\
\hline 1970 & 5,973 & 338,237 & 1975 & $10 \%$ & & 608,051 \\
\hline 1971 & 2,511 & 134,101 & 1976 & $10 \%$ & & 280.981 \\
\hline 1972 & 46 & 2,529 & 1977 & $10 \%$ & & 5,663 \\
\hline \multirow[t]{2}{*}{1973} & - & - & 1978 & - & & - \\
\hline & & $\$ 642.956$ & & & & 190.734 \\
\hline
\end{tabular}


patient in the regional acute cord injury center. This responsibility should extend, geography permitting, to the completion of primary definitive rehabilitation and for a life-long follow-up.

10. Consultants and specialists will revolve around the patient and the paraplegist.

11. Lifetime follow-up: A specially qualified visiting nurse is needed to integrate the follow-up of the spinal cord injured patients living outside hospital by paraplegist, family physician and urologist.

12. A modified concept of the role of the ambulance service is inescapable and urgently required to ensure rapid and safe transfer, within four hours of injury, to a regional acute cord injury center.

13. A radio controlled highway ambulance service must achieve:

(i) The provision of one ambulance attendant for each ambulance, trained and capable of reporting the clinical status of an acute cord injury patient by radio to the ambulance dispatcher, who must have professional back-up.

(ii) Transportation of the acute cord injury directly by road or by closely co-ordinated road and air ambulance services, including helicopters, to the regional acute cord injury center whenever the patient's condition permits; or to a hospital where air transport can be made available.

(iii) Stretchers designed to avoid rolling and sliding, and to maintain immobilization and to permit cervical traction, should be standard equipment.

(iv) Controlled, effective extrication of the victim and movement by ambulance attendants and police require continuing ongoing education.

ACUTE CORD INJURY PATIENTS SHOULD NOT BE ROUTINELY TRANSPORTED TO THE NEAREST HOSPITAL.

\section{ACKNOWLEDGEMENTS}

Personal acknowledgements and thanks are extended to Mrs. Nancy Lovelace. Mrs. Myrna Afari and Mrs. Linda Mitchell for their secretarial services, and $\mathrm{Mr}$. R. F. Irvine, Director of Medical Photography, Queen's University for the excellent prints.

\section{REFERENCES}

ALBIN, S., WHITE, R. J., ACOSTA-RUA, G. and YASHON, D. (1968). Study of Functional Recovery Produced by Delayed Localized Cooling After Spinal Cord Injury in Primates. Journal of Neurosurgery. 29, 113-119.

BOTTERELL, E. H. (1939). Presentation at Canadian Medical Association Meeting, Montreal, Quebec, 22 June 1939.

COYLE, T. F. and BULMER, E. (1975). Personal Communication.

CRUTCHFIELD, W. G. (1933). Skeletal Traction for Dislocation of the Cervical Spine, Report of a Case. Southern Surgeon, 2, 156-159.

DUCKER, T. B. and HAMIT, H. F. (1969). Experimental Treatments of Acute Spinal Cord Injury. Journal of Neurosurgery, 30, 693-697.

DUCKER, T. B. and LUCAS, J. (1974). Recovery from Spinal Cord Injury. Frontiers in Neurology and Neuroscience Research, $16,142-152$.

GALLIE, W. E. (1937). Skeletal Traction in the Treatment of Fractures and Dislocations of the Cervical Spine. Annals of Surgery, 106, 770-776.

GALLIE, W. E. (1939). Fractures and Dislocations of the Cervical Spine. American Journal of Surgery, 46, 495-499.

GILlinghaM, F. J. (1974). Personal Communication.

GINGRAS, G. (1973). Neglect of Urinary Tract and Kidneys in Paraplegic Patients Can Be Euthanasia in Disguise, CMA President Warns Doctors. Canadian Family Physician, 17, June 1973.

GREGG, T. M. and WILMOT, C. B. (1964). The Flying Squad and the Paraplegic Unit (Preliminary Report). Paraplegia, 2, 15-16.

GREGG, T. M. (1967). Organization of a Spinal Injury Unit Within a Rehabilitation Center. Paraplegia, 5, 163-166.

GREGG, T. M. (1975). Personal Communication.

GUTTMANN, L. (1949). Management of Paralysis. In: Intermittent Catheterization. British Surgical Practice, 6, 445.

GUTTMANN, L. and FRANKEL, H. (1966). The Value of Intermittent Catheterization in the Early Management of Traumatic Paraplegia and Tetraplegia. Paraplegia, 4, 63-83.

GUTTMANN, L. (1973). Spinal Cord Injuries: Comprehensive Management and Research. F. A. Davis, Philadelphia, 1973.

HACHEN, H. J. (1974). Emergency Transportation in the Event of Acute Spinal Cord Lesion. Paraplegia, 12, 33-37.
HEPBURN, A. L. (1975). Personal Communication.

JACKSON, R. W. (1975). Surgical Stabilization of the Spine. In press 1975 (to be published in Paraplegia, August, 1975).

JOUSSE, A. T., BREITHAUPT, D. J., WYNNE-JONES, $M$. and GEISLER, W. O. (1975). Personal Communication.

McKENZIE, K. G. (1935). Fracture, Dislocation and Fracture-Dislocation of the Spine. Canadian Medical Association Journal, 2, 263-269.

MEACHAM, W, F. and McPHERSON, W. F. (1973). Local Hypothermia in the Treatment of Acute Injuries of the Spinal Cord. Southern Medical Journal, 66, 95-97.

MEADOWS, D. H., MEADOWS, D. L., RANDERS, J. and BEHRENS, W. W. (111). (1972). The Limits to Growth: A Report for the Club of Rome's Project on the Predicament of Mankind. Earth Island Ltd., London, Potomac Associates Inc., Washington, D.C. Page 20.

MUNRO, D. (1936). Activity of the Urinary Bladder as Measured by a New and Inexpensive Cystometer. New England Journal of Medicine, 214, 517-624.

MUNRO, D. (1943). Tidal Drainage and Cystometry in the Treatment of Sepsis Associated with Spinal Cord Injuries: A Study of 165 Cases. New England Journal of Medicine, 229, 6-14.

OSTERHOLM, J. L. (1974). The Pathophysiological Response to Spinal Cord Injury: The Current Status of Related Research. Journal of Neurosurgery, 40 , 5-33.

PEARMAN, J. W. and ENGLAND, E. J. (1973). The Urological Management of the Patient Following Spinal Cord Injury. Charles C. Thomas, Springfield, IIl.

PEERLESS, S. J. and SCHWEIGEL, J. F. (1974). The Medical and Economic Fate of Twenty-Nine Industrial Spinal Cord Injured Patients. Paraplegia, 12, 145-150.

ROMERO-SIERRA, C., HANSEBOUT, R., SIERHUIS, A. and LEWIN, M. (1974). A New Method for Localized Spinal-Cord Cooling. Medical and Biological Engineering. 12, 188-193.

ROSSIER, A., BERNEY, J., ROSENBAUM, A. and HACHEN, J. (1973). The Value of Gas Myelography in the Early Management of Acute Cervical Spinal Cord Injuries. Presented at the Joint Conference of the International Medical Society of Paraplegia and the U.S. Veterans Administration Spinal Cord Injury Conference, Scottsdale, Arizona, October 1973 and at a meeting of the American Association of Neurological Surgeons, St. Louis, Missouri, April 1974. (To be published in the Journal of Neurosurgery.)

TATOR, C. H. and DEECKE, L. (1973). Value of normothermic perfusion, hypothermic perfusion and durotomy in the treat ment of experimental acute spinal cord trauma. Journal of Neurosurgery, 39, 52-64.

TATOR. C. H. (1974). Personal Communication. 